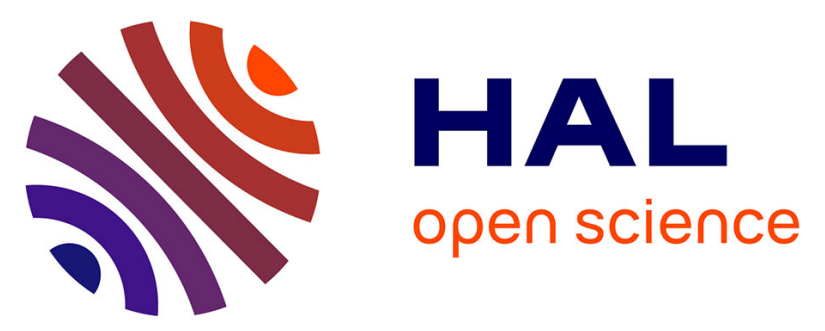

\title{
Lateglacial-Holocene abrupt vegetation changes at Lago Trifoglietti in Calabria, Southern Italy: The setting of ecosystems in a refugial zone
}

Jacques-Louis de Beaulieu, Elisabetta Brugiapaglia, Sebastien Joannin, Frédéric Guiter, Giovanni Zanchetta, Sabine Wulf, Odile Peyron, Liliana Bernardo, Julien Didier, Agnès Stock, et al.

\section{To cite this version:}

Jacques-Louis de Beaulieu, Elisabetta Brugiapaglia, Sebastien Joannin, Frédéric Guiter, Giovanni Zanchetta, et al.. Lateglacial-Holocene abrupt vegetation changes at Lago Trifoglietti in Calabria, Southern Italy: The setting of ecosystems in a refugial zone. Quaternary Science Reviews, 2017, 158, pp.44 - 57. 10.1016/j.quascirev.2016.12.013 . hal-01662646

\section{HAL Id: hal-01662646 https://hal.science/hal-01662646}

Submitted on 7 May 2018

HAL is a multi-disciplinary open access archive for the deposit and dissemination of scientific research documents, whether they are published or not. The documents may come from teaching and research institutions in France or abroad, or from public or private research centers.
L'archive ouverte pluridisciplinaire HAL, est destinée au dépôt et à la diffusion de documents scientifiques de niveau recherche, publiés ou non, émanant des établissements d'enseignement et de recherche français ou étrangers, des laboratoires publics ou privés. 


\title{
Lateglacial-Holocene abrupt vegetation changes at Lago Trifoglietti in Calabria,
} Southern Italy: The setting of ecosystems in a refugial zone

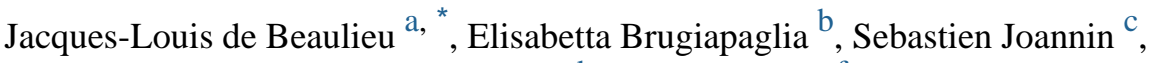 \\ Frederic Guiter ${ }^{\mathrm{a}}$, Giovanni Zanchetta ${ }^{\mathrm{d}}$, Sabine Wulf ${ }^{\mathrm{e}, \mathrm{f}}$, Odile Peyron ${ }^{\mathrm{c}}$, Liliana Bernardo ${ }^{\mathrm{g}}$, Julien \\ Didier $^{h}$, Agnes Stock ${ }^{h}$, Damien Rius ${ }^{h}$, Michel Magny ${ }^{h}$ \\ a Aix Marseille Univ, CNRS, IRD, IMBE, UMR 7263 \& 237, Aix-en-Provence, France \\ b Universita degli Studi del Molise, Dipartimento di Agricoltura, Ambiente e Alimenti, Campobasso, Italy

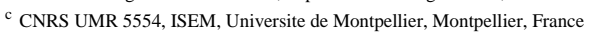 \\ d Dipartimento di Scienze della Terra, Universita di Pisa, Italy \\ e Senckenberg Research Institute and Natural History Museum, BIK-F, TSP6 Evolution and Climate, Frankfurt/Main, Germany \\ ${ }^{\mathrm{f}}$ Institute of Earth Sciences, Heidelberg University, Germany \\ ${ }^{\mathrm{g}}$ Dipartimento DiBEST, Universita della Calabria, Italy \\ ${ }^{\text {h }}$ Laboratoire Chrono-Environnement UMR 6249 du CNRS, UFR des Sciences et Techniques, Besançon, France
}

Keywords:

Lake sediments

Calabrian Mountains

Lago Trifoglietti

Pollen record

LGI-early Holocene

Preboreal oscillation

Tephrochronology

Glacial refuges a bstract

Retrospective science such as palaeoecology deeply depends on the preservation of archives in sensitive places. As an example, mountains of medium altitude from Mediterranean peninsulas have long been identified by biogeographers as refuges zones allowing the survival of European temperate taxa during the ice ages, but archives to validate this hypothesis are scarce, especially in Southern Italy. Here we present a new sequence from Lago Trifoglietti (1048 m a.s.l.) in the Calabrian Mountains, which covers

the Late Glacial Interstadial (LGI, corresponding to the Bolling€-Allerod€ period in northern-central Europe) and the transition to the Holocene. The independent chronology based on seven radiocarbon dates is supported by the evidence of three tephra layers already identified in other regional sequences. During the LGI, besides the high diversity of non arboreal pollen grains, a great number of pollens of temperate forest trees are present or abundant (mostly deciduous oaks and fir). These assemblages suggest that the site was above but not far from the upper limit of diversified woodland stands. They confirm a local survival during the last glacial. The Younger Dryas is not marked by major changes, and oak percentages are even higher, suggesting a resilient expansion at lower altitude. Surprisingly the site remains above the timberline until an aridity crisis centered at 11,100 cal ${ }^{14} \mathrm{C}$ yr PB, which is correlated with the Pre-boreal Oscillation (PBO). This event is immediately followed by the local settlement of a dense fir and beech forest around the lake. A comparison with other Italian key sequences aims at explaining the climate forcing factors that governed this original vegetation dynamic. Further investigations using additional proxies are needed for a more robust climate reconstruction.

\section{Introduction}

The Lateglacial to Holocene transition constitutes a key period for the setting of temperate ecosystems, from which the present landscape is inherited. This is particularly true in the Mediterra-nean peninsulas whose role as refugial zones during the glacial times has been evidenced both by palaeoecological and phylo-geographical studies (Hewitt, 2011). One can expect a two dimen-sional expansion (i.e. altitudinal and latitudinal) of temperate forest starting during the Lateglacial Interstadial (LGI) or quickly 
following the postglacial warming, without significant lags due to migrations from more distant refuges. Nevertheless these dynamics cannot be fully understood without palaeo-data providing knowl-edge about the period corresponding to the setting of the Late-glacial warming. Unfortunately this period is poorly documented in Southern Italy, with the exception of the record obtained from the site of Lago Grande di Monticchio (Huntley et al., 1999; Allen et al., 2002) (Fig. 1). In Calabria a pollen study of the sediment infill of the Mountain lake of Trifoglietti constitutes a promising target to fill this gap. The study of a first coring from this site has recently provided a reconstruction of the local vegetation and hydrological changes since ca. 11,500 cal yr BP within a more extensive project focussing on the Central Mediterranean area (Joannin et al., 2012; Magny et al., 2013, Peyron et al., 2013). The sequence shows a phase characterized by open steppe vegetation apparently contemporaneous with the Preboreal Oscillation (PBO) based on three radiocarbon dates; this event is followed by the expansion of beech-fir woodland at ca. $11,000{ }^{14} \mathrm{C}$ cal yr BP. Such extremely arid event, never evidenced before, was rather difficult to understand without data for the preceding Lateglacial vegetation. A new coring campaign has been performed in autumn 2011, which allowed collecting a sequence beginning with the LGI and evidencing several tephra layers. The objectives of this study are fourfold as follow: $1 /$ to contribute in the description of the local environment history of Calabria during the Lateglacial, 2/ to establish the importance of this region as a possible refugium for temperate trees during the Lateglacial, 3/ to assess the regional impact of the Younger Dryas (YD) cold event, 4/ to test more robustly the regional significance and timing of the early Holocene, short-lived arid even (the 'Trifoglietti event'), as a possible correlative of the PBO.

\section{General description of the site}

\subsection{Location}

Lago Trifoglietti ( $3933^{0} \mathrm{~N}, 1601^{0} \mathrm{E} ; 1048 \mathrm{~m}$ a.s.l.) is located in Calabria (Southern Italy) (Fig. 1), near the town of Fagnano Castello in Cosenza province. The lake, overlooked by Monte Caloria

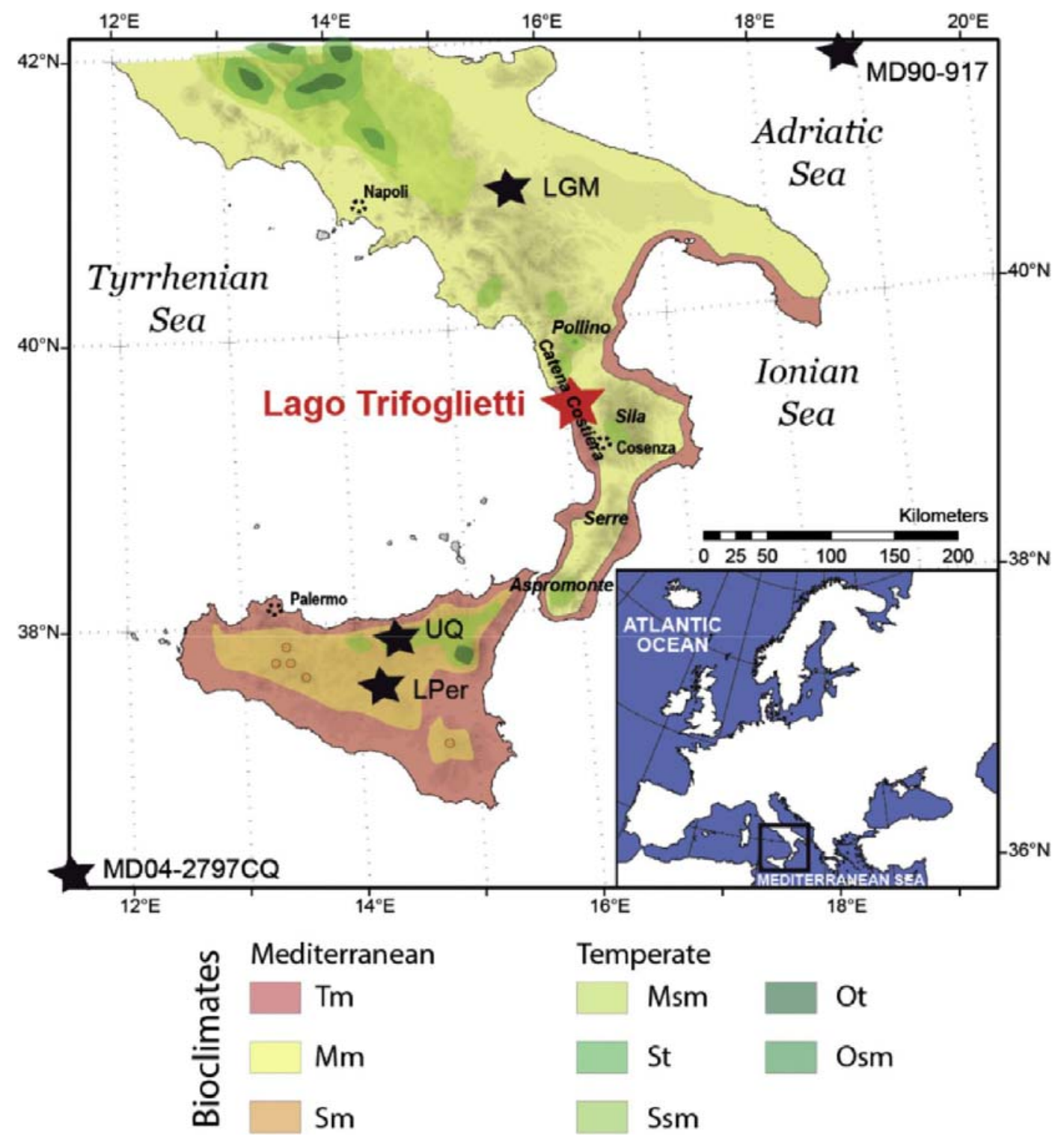

Fig. 1. Location of the study site and other sites considered in the text: Lago Grande di Monticchio (Allen et al., 2002), Urio Quattrocchi (Bisculm et al., 2012), Lago di Pergusa (Sadori and Narcisi, 2001), MD90-917 (Siani et al., 2012; Combourieu-Nebout et al., 2013), MD04-2797CQ (Desprat et al., 2013). Bioclimatic belts issued from Rivas Martinez's classification (1993), modified after Spampinato et al. (2010). 
(1183 m), is part of a natural high-altitude lacustrine system in the Catena Costiera Mountains which stretch along and parallel to the Tyrrhenian coast for $70 \mathrm{~km}$ with altitudes ranging from 1060 to $1541 \mathrm{~m}$ (Sperone et al., 2007). The slope toward the sea is steep and thus the horizontal distance from the lake to the sea is only $16 \mathrm{~km}$.

At Trifoglietti, a spring currently flows into the lake from the north; an outflow runs southward (Fig. 2aeb). To combat summer drought and a complete infilling, the Municipality of Fagnano Castello built a small earthen dam in 2000. With a surface area of 0.973 ha and a catchment area covering $0.370 \mathrm{~km}^{2}$, the lake, largely occupied by swamp vegetation, reaches a depth of up to $1.50 \mathrm{~m}$. The aquatic lake vegetation comprises a mosaic of different plant communities, with dominant Carex paniculata tussocks, partly linked with dynamic successions due to variations in water level. A detailed description of the site is available in Joannin et al. (2012).

\subsection{Climate and phytogeography}

\subsubsection{Climate}

Due to its geographical position and to its relatively high elevation, the climate of the Trifoglietti region is greatly influenced by warm and humid air masses from the Tyrrhenian Sea. Despite the strictly Mediterranean latitude of the study area, annual rainfall can reach more than $1800 \mathrm{~mm} /$ year, with a summer dry period relatively short (Ciancio, 1971). According to the bioclimatic clas-sification proposed by Rivas-Martinez (1993) and based on both a corrected summer ombrothermic index (Iovc) and a corrected thermic index (Itc), the Trifoglietti area falls within the "lower mesotemperate bioclimate belt" of a temperate region and the ombrotype is "upper hyperhumid". Mean annual temperature is $15 \mathrm{C}$, with $24 \mathrm{C}$ for August and 7.5 C for January.

\subsubsection{Geology and phytogeography}

Located at latitudes between $4010^{0}$ and $3755^{\circ} \mathrm{N}$ and longitudes between $1540^{0}$ and $1710^{0}$ E, Calabria covers an area of $15.082 \mathrm{~km}^{2}$, half of it consisting of hills up to $600 \mathrm{~m}$ a.s.l., and about $41 \%$ of mountains. The maximum altitude is reached by Mount Serra Dolcedorme (2267 m a.s.l.).

Calabrias's palaeobiogeographical history dates to the Palae-ozoic era and is extremely complex. Although the Calabrian mountains show an orographic continuity with the Apennine chain, there are remarkable geological differences between them. Almost the entire territory of Calabria consists of a large geological unit, called the Calabrian-Peloritan arc, which is lithologically and evolutionary completely different from the central Apennines (Ogniben, 1973; Amodio-Morelli et al., 1976). This unit is composed of sedimentary rocks of different ages and types. The backbone of the Calabrian-Peloritan arc consists of igneous and metamorphic rocks similar to the Corsica-Sardinia block, both derived from a portion of the western Alps. During the Miocene, the Calabrian-Peloritan arc migrated towards its current position; here, it wedged and partially overlaid the younger rocks of the Apennines (Van Dijk et al., 2000). All these lithotypes produced a wide variety of soils and plant communities; the latter thus simultaneously belonging to the Temperate and Mediterranean bioclimatic regions (Blasi and Michetti, 2007). According to Rivas Martinez's classifi-cation (1993), we can distinguish four bioclimatic belts (Fig. 1; Spampinato et al., 2010) as follows.

- The Thermomediterranean belt (Tm), which embraces the coastal areas and low hills of the region. Here the woody com-munities are very thin and fragmented into small patches. They are represented by the evergreensclerophyllous maquis and, on particularly cool and shady slopes, by thermophilous deciduous

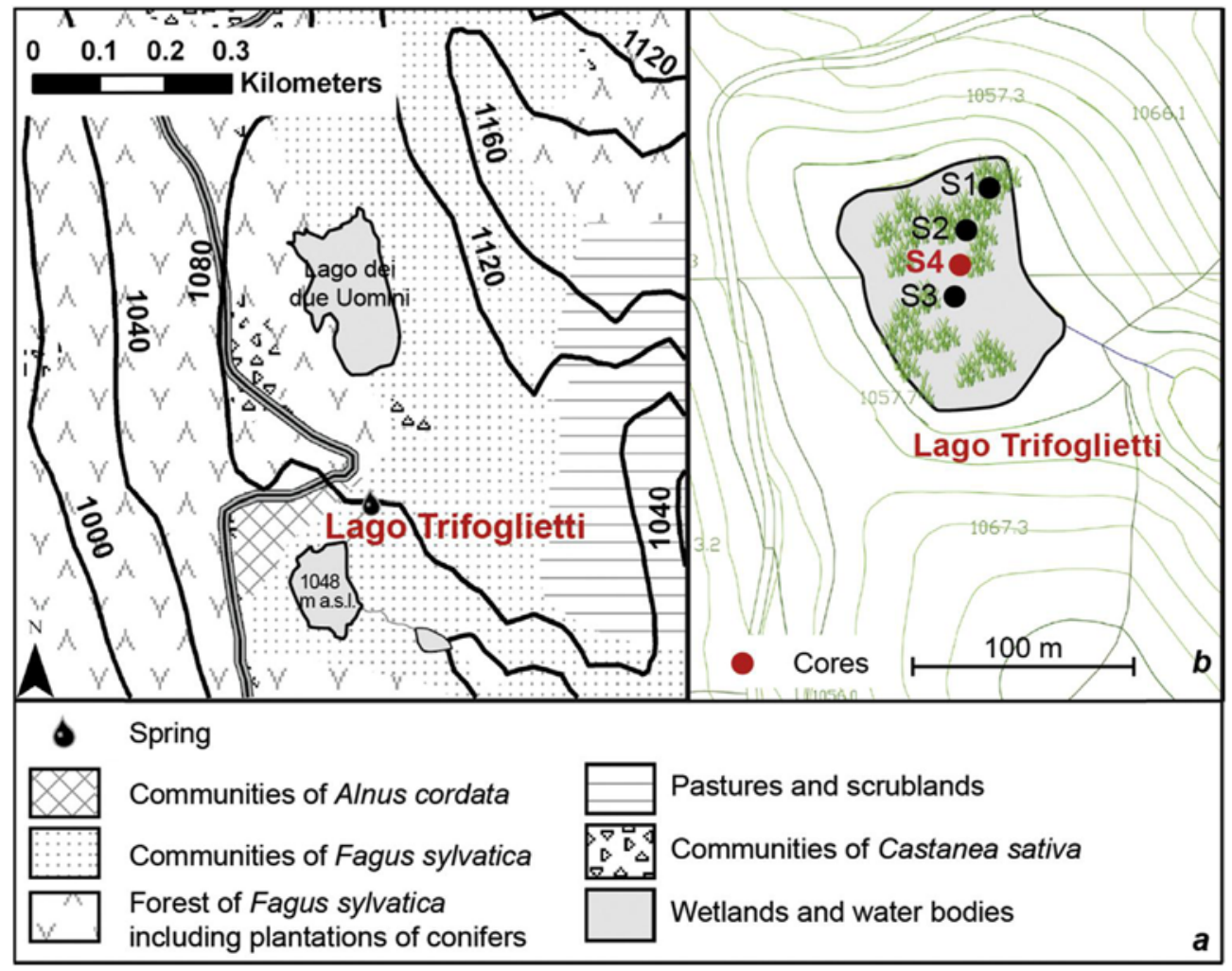

Fig. 2. a) Actual vegetation map; b) coring sites of campaign 2009 (S1-S3; Joannin et al., 2012) and 2011 (S4, this study). 
forests where Quercus virgiliana is typically occurring. Currently, a wide portion of this territory is occupied by crops, especially olive groves, besides urban infrastructures.

- The Mesomediterranean belt (Mm) shows a wide extension throughout the region and is positioned in altitudes between $200-400$ and $800 \mathrm{e} 1000 \mathrm{~m}$. The vegetation consists of evergreen forests where Quercus ilex is dominant, especially on the southern steepest Tyrrhenian slopes (Serre and Aspromonte). On the other hilltops, thermophilous, deciduous forests with

Q.virgiliana or, in cooler and moister conditions, with Q. frainetto prevail.

- The Supramediterranean belt (Sm), between 800-1000 and 1100e1200 m altitude, is well represented in the region, espe-cially on the Ionian side, and is characterized by deciduous oak forests consisting of various species, such as, above all, Quercus cerris and Q. frainetto, but also Q. congesta, Q. pubescens and

Q. dalechampii, in pure or mixed forests.

Quite often, the deciduous oak forests are replaced by cultivated Castanea sativa pure stands.

The most shaded and sunken valleys are characterized by forests with Ostrya carpinifolia, Acer spp., Carpinus betulus and Corylus avellana as prevailing species.

- In the Supratemperate belt (St) beech woods prevail on wide areas at an altitude ranging between 900-1000 m and 1900e2000 m, but descending down to $500 \mathrm{e} 600 \mathrm{~m}$ along the narrow valleys of the Tyrrhenian side. On the Calabrian moun-tains, the beech woods may be ascribed to three distinct asso-ciations. The first, called Anemono-Fagetum, prevailing under $1500 \mathrm{~m}$, is influenced by the oceanic climate and it is charac-terized by abundant undergrowth of Ilex aquifolium. The second is the Galio hirsuti-Fagetum, which mainly occurs, as requiring a less oceanic climate, on the southern and western side of the Aspromonte massif. From 1500 to $1600 \mathrm{~m}$ a.s.l. up to almost $2000 \mathrm{~m}$ the third association, the Campanulo trichocalicinae-Fagetum, is adapted to a colder climate, where beech trees reach their maximum altitudinal limit. In the various types of wood-lands, beech trees tend to form pure stands, although often associated with Abies alba, which generally has a subordinate role. Silver fir trees become dominant only on small areas of the Aspromonte, at about $1600 \mathrm{~m}$, on windy, rocky peaks.

Native woodlands characterized by Pinus nigra ssp. laricio occur on crystalline tops (Sila and Aspromonte), between 1000 and 1400 m a.s.l., on steep and sunny slopes, where the soil is poor. However, nowadays this species is widespread on all the Calabrian mountains, thanks to its successful use as species for reforestation. In the most depressed areas of these highlands there are a few small wetlands, swamps and bogs of a great natural value, because they are propitious to the establishment of some boreal species at their southernmost distribution edge.

On Sila plateau, but also on Serre and Aspromonte the natural forests have been often removed and replaced by cereals and potato crops or by coniferous planting. Crop abandonment causes the spread of Sarothamnus scoparius, forming dense thickets.

Only on the Pollino massif, where a few peaks reach or exceed $2000 \mathrm{~m}$ of altitude, we can distinguish a timberline, above which there are the typical prairies and rocky communities of the Apen-nine high-mountain belt. In this context, the Bosnian pine (Pinus heldreichii var. leucodermis) has colonised steep rocky slopes.

The Catena Costiera vegetation is dominated by Fagus sylvatica, Quercus cerris and Castanea sativa.

Lake Trifoglietti is surrounded by a beech forest attributed to Anemonoapenninae-Fagetum with some Pinus nigra subsp. laricio.
Scrub vegetation, with Erica arborea, Cistus salvifolius, Helichrysum italicum, Sarothamnus scoparius and Alnus cordata trees, develops in the more open Fagus forests.

\section{Material and methods}

\subsection{Core sampling}

The 2009 study of the Lake Trifoglietti sequence demonstrated its palaeoecological importance and stimulated the present research, which extends the record into the Lateglacial.

Fig. 2b recalls the transect of cores realized in 2009 (S1, S2, S3): the studied core was S2 (called here Trifo.09). In October 2011, a new coring was undertaken at a point S4 (approximately between S2 and S3 and labeled here Trifo.11), with the help of the Fagnano Castello local authority. Coring was carried out using a $1 \mathrm{~m}$ long Russian peat corer with an $8 \mathrm{~cm}$ diameter chamber. The upper $11 \mathrm{~m}$ of the peat sequence were discarded and core sections extracted from $11 \mathrm{~m}$ to the substratum at $15.95 \mathrm{~m}$ (coarse gravel layers) were retained for further analyses. As the tip of a Russian corer penetrates ca. $10 \mathrm{~cm}$ below a core, the upper part of the next core is disturbed. Therefore, after the first core sequence (here named Trifo. 11.1) obtained, a parallel twin sequence (Trifo.11.2) was retrieved to allow a 'master core sequence' to be generated by matching key reference lithological horizons, magnetic suscepti-bility variations and tephra markers (see below and Fig. 3). Core segments were extracted on site, wrapped in plastic, transported and stored at $4 \mathrm{C}$ at the University of Franche-Comte where lith-ological description, magnetic susceptibility measurements and sub-sampling for pollen analysis, ${ }^{14} \mathrm{C}$ measurements and tephra analyses were undertaken.

\subsection{Magnetic susceptibility}

The cores were photographed and logged with a GEOTEK Multi Sensor Core Logger in order to obtain geophysical measurements, scanning of lithology, measurements of magnetic susceptibility (MS) at $0.5 \mathrm{~cm}$ intervals. This study focuses on the master core constructed from the twin cores (Trifo.11.1 and Trifo.11.2, Fig. 3).

The MS is mainly dependent on magnetite concentration in sediments. It was measured in electromagnetic units to determine the inorganic allochtonous sediment content (Gedye et al., 2000). As the development of pedogenesis under forest cover may have favored a mineral magnetic increase in soils (Jong et al., 1998), low magnetic concentrations recorded in sediments is to be expected during phases of stabilized vegetated slopes (Whitlock et al., 2011), while increased MS may be related to changes in sediment sources and to erosive processes of soils (Vanniere et al., 2013). Neverthe-less, when ferrimagnetic mineral concentration is low (magnetite and maghaemite), the value of MS may be largely influenced by diamagnetic minerals (quartz, carbonates) (Thompson and Oldfield, 1986).

\subsection{Tephra study}

Samples of macroscopic visible tephra layers were embedded in epoxy resin and screened for volcanic glass shard fragments using scanning electron microscopy (SEM). Energy-dispersive-spectrometry (EDS) analyses of glass shards were carried out us-ing an EDAX-DX micro-analyser mounted on a Philips SEM 515 at the Dipartimento di Scienze della Terra, University of Pisa, employing a $20 \mathrm{kV}$ acceleration voltage, $100 \mathrm{~s}$ live time counting, $2100 \mathrm{e} 2400$ shots per second, and ZAF corrections (Z $1 / 4$ Atomic number correction, A $1 / 4$ Adsorbion correction, F $1 / 4$ Fluorescence correction). The ZAF correction procedure did not include natural or 

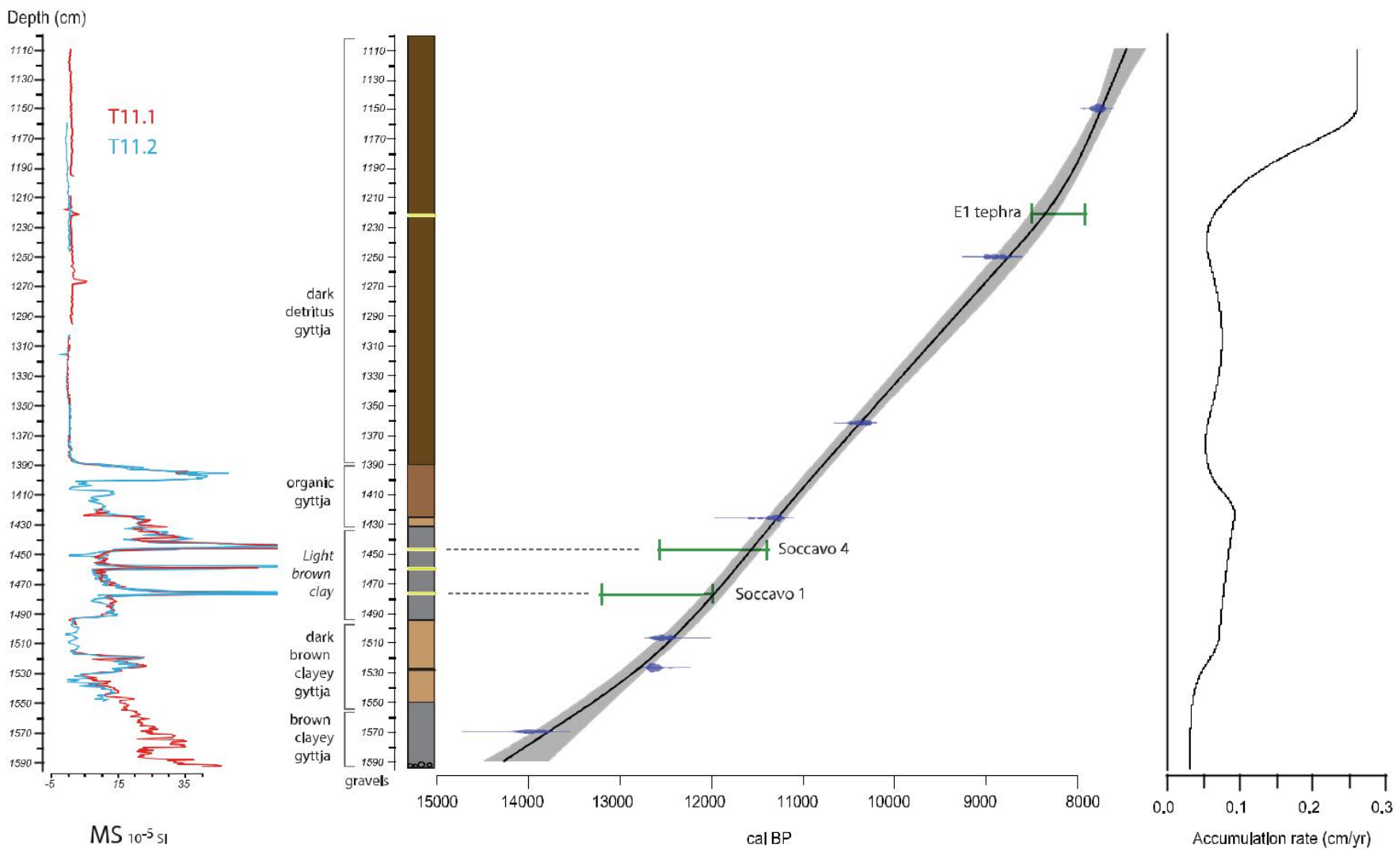

Fig. 3. Magnetic Susceptibility (MS), lithology and age-depth model of the Trifoglietti. master core (MC) based on radiocarbon calibrated ages (AMS, see Table 1).

synthetic standards for reference, and this required the results to be normalized to a given value (which was chosen at $100 \%$ ). We used two standards whose chemistry has been accurately obtained using XRF analyses and certified have been routinely analyzed in the Pisa laboratory: a trachyte glass (CR1) and an Albite along with the Zagarbard scapolite (Marianelli and Sbrana, 1998). To avoid alkali loss, especially Na, a window spot usually ca. $10 \mathrm{~mm}$ wide was used. Due to the different shapes and sizes of glass shards, sometimes a smaller beam size had to be used. The use of smaller beam sizes obligate to reduce the size of the defocused beam and this could influence analytical data due to the complex combination of element mobility and sample damage (Hunt and Hill, 2001). However, this was minimized by analyzing many different shards from the same sample. No obvious differences were observed be-tween results from smaller and larger shards. Analytical precision was $0.5 \%$ for abundances higher than $15 \mathrm{wt} \%, 1 \%$ for abundances around $5 \mathrm{wt} \%, 5 \%$ for abundances of $1 \mathrm{wt} \%$, and less than $20 \%$ for abundances close to the detection limit, i.e. around $0.5 \mathrm{wt} \%$ (Marianelli and Sbrana, 1998). Several trials for comparing the performance of the Pisa SEM-EDS with wave dispersion spectros-copy (WDS) have been extensively discussed by Cioni et al. (1997), Marianelli and Sbrana (1998), Vogel et al. (2010), Sulpizio et al. (2010) and Caron et al. (2010, 2012).

\subsection{Chronology}

The chronology is based on seven Accelerator Mass Spectrom-etry (AMS) ${ }^{14} \mathrm{C}$ ages measured on terrestrial organic material (Table 1) at Poznan Radiocarbon Laboratory. Conventional ${ }^{14} \mathrm{C}$ ages were calibrated using the IntCal13 curve (Reimer et al., 2013) based on the 2S range interval. Six samples (composed of terrestrial macro-remains) were taken from the Trifo.11.1 cores and one from a twin section of Trifo.11. 2 core (depth and corresponding depth on the master section are reported in Table 1). The age-depth model (Fig. 3) has been computed using the module R Clam of Blaauw (2010) based on a smoothspline (smooth: 0.3). Timings derived from the age-depth model are reported in cal ${ }^{14} \mathrm{C}$ yr BP (1950) with a two sigma error range, and positions of tephra layers are pre-sented in the curve with their respective chronological intervals according to the information in section 4.1.2. Ages have been extrapolated beyond upper and lower dated levels.

\subsection{Pollen analysis}

Sediment samples of $1 \mathrm{~cm}^{3}$ of volume were treated both chemically $(\mathrm{HCl}$, $\mathrm{KOH}, \mathrm{HF}$, acetolysis) and physically (sieving) following standard procedures (Moore et al., 1991). Samples were taken at $10 \mathrm{~cm}$ resolution from 11 to $12 \mathrm{~m}$ (previously studied in-terval), and either 5 or $2.5 \mathrm{~cm}$ from $12 \mathrm{~m}$ to the base of the core. A sum of at least 300 terrestrial pollen grains was counted, excluding dominant terrestrial taxa. A total of 151 pollen samples were analyzed under light microscopes at a magnification of either 400 or 500.178 pollen types were identified using photo atlases (Reille, 1992e1998; Beug, 2004) and reference collections. Oak pollen grains are always difficult to determine at the species level and the great number of oak species growing in Calabria increases the risks of errors. We identified three pollen types (Quercus robur type, Quercus suber/cerris type and Quercus ilex type). But the morphologies of the two first types frequently overlap: on the di-agram (Fig. 4) there are merged as "deciduous oaks". Percentages were calculated based on the total pollen sum. The number of spores and algae counted were added to the pollen sum when calculating their relative percentages. Other Non Pollen Paly-nomorphs (NPP) were explored, but their study is not completed 
Summary of radiocarbon dates obtained from the Trifo. 11 core (four dates from Trifo.09, in italics, illustrate the correlation between the two cores).

\begin{tabular}{|c|c|c|c|c|c|c|}
\hline Sample code (Lab number) & Nature of sample & Core & Master core depth (m) & $\mathrm{PAZ}$ & Uncalibrated ${ }^{14} \mathrm{C}$ age (yr BP) & Calibrated ages at two $\mathrm{S}$ range $\left(\mathrm{cal}{ }^{14} \mathrm{C}\right.$ yr BP$)$ \\
\hline Poz-64307 & Twigs & Trifo.11.1 & 11.50 & $\mathrm{~T} 11-12$ & $6930 \pm 40$ & $7677 \mathrm{e} 7844$ \\
\hline Poz-64308 & Twigs & Trifo.11.1 & 12.51 & $\mathrm{~T} 11-12$ & $8010 \pm 50$ & 8668 e9016 \\
\hline Poz-64309 & Twigs & Trifo. 11.1 & 13.62 & $\mathrm{~T} 11-8$ & $9200 \pm 50$ & $10,247 \mathrm{e} 10,496$ \\
\hline Poz-50604 & Twigs & Trifo.11.1 & 14.26 & $\mathrm{~T} 11-8$ & $9900 \pm 60$ & $11,205 \mathrm{e} 11,602$ \\
\hline Poz-72557 & Twigs & Trifo.11.2 & 15.07 & $\mathrm{~T} 11-4$ & $10,560 \pm 60$ & $12,395 \mathrm{e} 12,685$ \\
\hline Poz-50605 & Twigs & Trifo.11.1 & 15.27 & $\mathrm{~T} 11-3$ & $10,670 \pm 60$ & $12,548 \mathrm{e} 12,719$ \\
\hline Poz-50606 & Twigs & Trifo. 11.1 & 15.70 & $\mathrm{~T} 11-2$ & $12,120 \pm 80$ & $13,765 \mathrm{e} 14,171$ \\
\hline Poz-33812 & Twigs & Trifo. 09 & 7.61 & T-3a & $9335 \pm 60$ & $10,290 \mathrm{e} 10,710$ \\
\hline Poz-33813 & Twigs & Trifo. 09 & 8.06 & T-3a & $9630 \pm 60$ & $10,760 \mathrm{e} 11,190$ \\
\hline Poz-41168 & Twigs & Trifo. 09 & 8.43 & $\mathrm{~T}-1$ & $9850 \pm 50$ & $11,190 \mathrm{e} 11,388$ \\
\hline Poz-33836 & Twigs & Trifo. 09 & 8.43 & $\mathrm{~T}-1$ & $9940 \pm 60$ & $11,220 \mathrm{e} 11,690$ \\
\hline
\end{tabular}

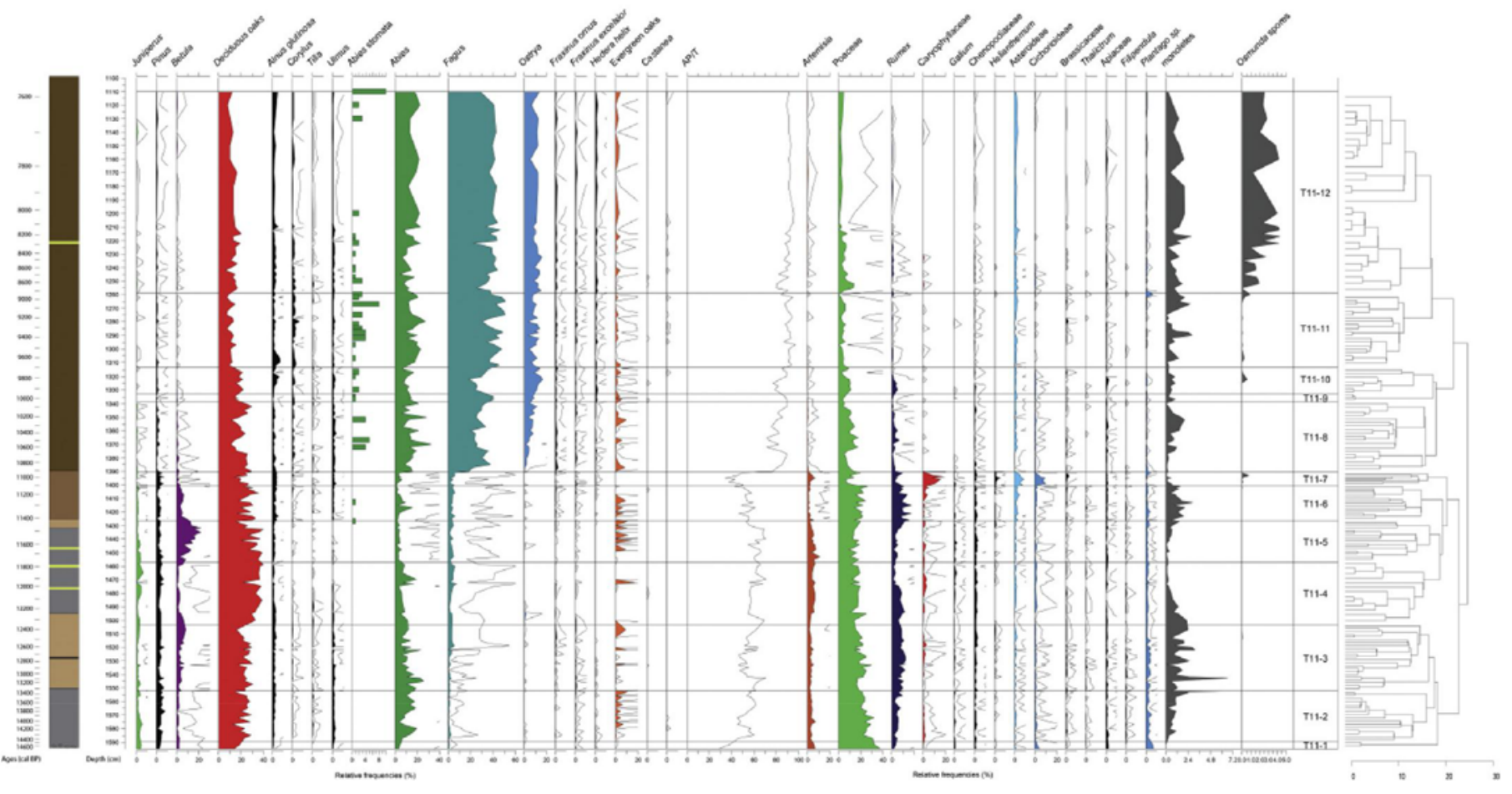

Fig. 4. Simplified pollen diagram of Lago Trifoglietti.

yet and the simplified pollen diagram will shows only Abies stomata and Asterosporium conidiae which are useful in the discussion.

Using the C2 program (Juggins, 2007), a pollen diagram of selected taxa is provided in Fig. 4. Fig. 5 presents in more detail the non-arboreal pollen (NAP) and algae. Rare taxa appear in Table 2. Subdivision into 12 biozones (Pollen Assemblage Zones, PAZ: from T11-1 to T11-12) was defined by cluster analysis based on the Coniss algorithm (Grimm, 1987) using the Rioja package (Juggins, 2012).

\section{Results}

\subsection{Sediment and age/depth model}

\subsubsection{Lithology}

Below the detritus gyttja deposits that are similar to those previously described for the S2 core are clay-gyttja deposits, not previously recorded from the Trifoglietti basin. In detail, the latter show the following lith-facies units from $11 \mathrm{~m}$ depth to the base of the recovered sequence:
- 11.00e13.97 m: dark detritus gyttja. Issued from an exploratory core, Fig. 6 shows the structure of this detritus gyttja, i.e. an accumulation of leaves (here Fagus), Abies needles and wood fragments. A thin millimetric fine sand layer (identified as tephra 1) was observed at $12.20 \mathrm{~m}$.

- 13.97e14.30 m: black clay gyttja including a succession of millimetricscale organic layers between $14.20 \mathrm{~m}$ and $14.25 \mathrm{~m}$.

- 14.30e14.95 m: light brown clay including three sandy layers at levels $14.44 \mathrm{e} 45 \mathrm{~m}, 14.60 \mathrm{~m}$ and $14.77 \mathrm{e} 78 \mathrm{~m}$ (the upper and the lower ones were identified as in situ tephra: see below).

- 14.95e15.50 m: dark brown clay-gyttja darkening towards the top, with a succession of millimetric-scale organic layers be-tween levels $15.10 \mathrm{~m}$ and $15.15 \mathrm{~m}$.

- 15.50e15.95 m: brown clay-gyttja (sharp contact at $15.50 \mathrm{~m}$ ), with sporadic white dots of vivianite between $15.10 \mathrm{~m}$ and $15.80 \mathrm{~m}$.

- 15.95 m: top of a coarse gravel layer (limit of coring).

\subsubsection{Tephra analyses}

Four distinct visible tephra layers have been identified at $12.2 \mathrm{~m}$, 
J.-L. Beaulieu et al.

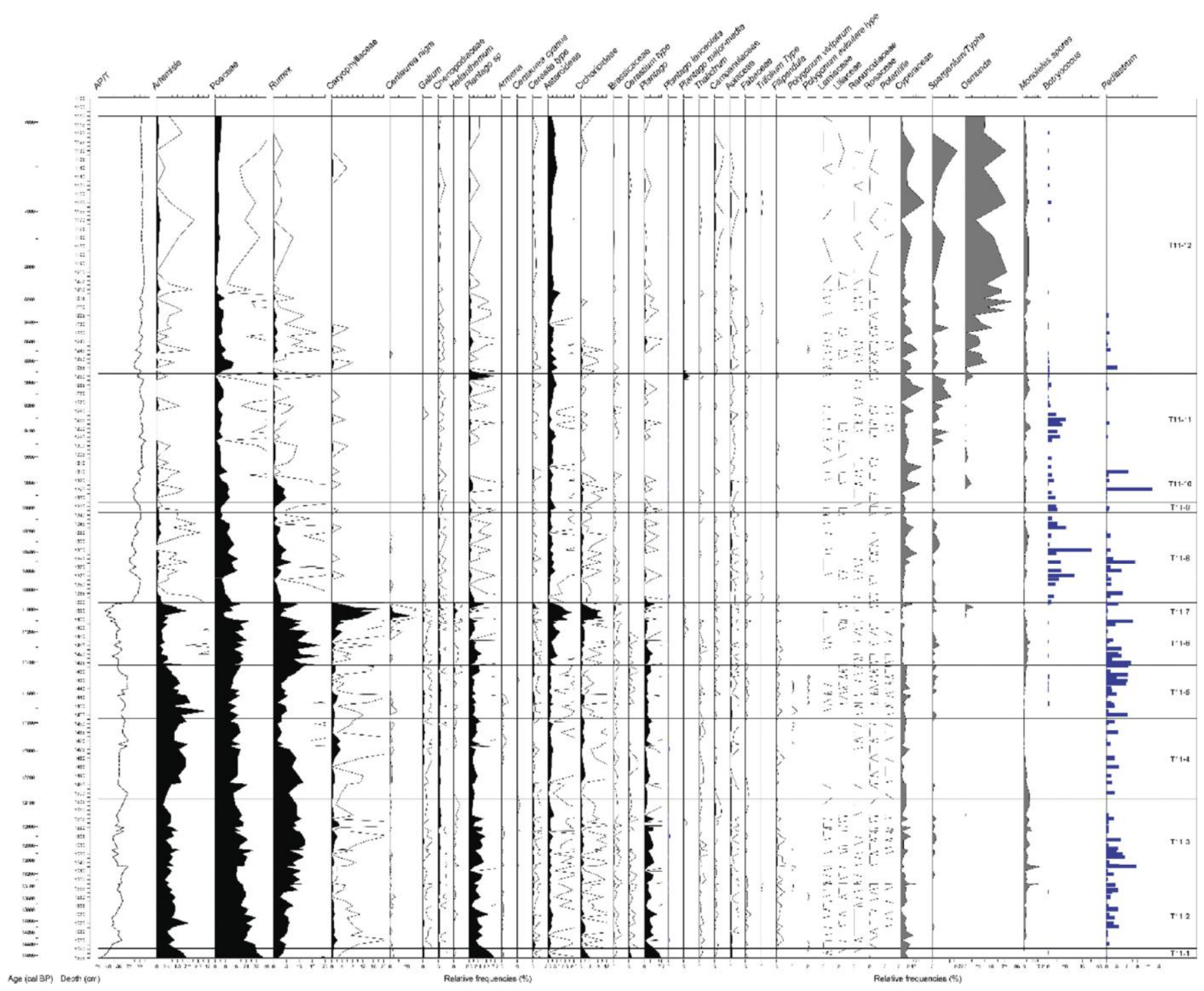

Fig. 5. Pollen diagram with algae.

Table 2

Rare pollen taxa occurring in the Trifoglietti 11 core.

\begin{tabular}{ll}
\hline TAXON & Depth $(\mathrm{m})$ \\
\hline Arcetobium oxycedri & 15.15 \\
Calligonum & 15.53 \\
Cerinthe & 12.82 \\
Cheylanthes & $12.30 \mathrm{e} 12.87$ \\
Cladium & $13.72 \mathrm{e} 13.60 \mathrm{e} 13.52 \mathrm{e} 13.45 \mathrm{e} 13.35 \mathrm{e} 12.88 \mathrm{e} 11.60 \mathrm{e} 11.30$ \\
Cynoglossum/Anchusa & 14.40 \\
Daphne & $15.95 \mathrm{e} 14.72$ \\
Epilobium & $15.75 \mathrm{e} 15.72 \mathrm{e} 14.85$ \\
Erica terminalis & 12.95 \\
Euphorbia & $15.82 \mathrm{e} 15.72 \mathrm{e} 15.65 \mathrm{e} 15.35 \mathrm{e} 14.55 \mathrm{e} 14.17 \mathrm{e} 13.40 \mathrm{e} 12.12$ \\
Gentiana & $15.82 \mathrm{e} 15.72 \mathrm{e} 15.22 \mathrm{e} 14.48 \mathrm{e} 14.37 \mathrm{e} 13.85 \mathrm{e} 12.52 \mathrm{e} 11.32$ \\
Linum & $15.77 \mathrm{e} 15.33 \mathrm{e} 15.32 \mathrm{e} 15.15 \mathrm{e} 14.65$ \\
Lysimachia & $13.20 \mathrm{e} 13.12 \mathrm{e} 12.65 \mathrm{e} 12.60 \mathrm{e} 12.40 \mathrm{e} 12.18 \mathrm{e} 12.20$ \\
Pinguicula & $15.20 \mathrm{e} 14.65 \mathrm{e} 14.50 \mathrm{e} 11.30$ \\
Polypodium & 11 samples above 13.30 \\
Theligonum cynocrambe & $12.75 \mathrm{e} 13.07 \mathrm{e} 15.37 \mathrm{e} 15.72$ \\
Vitis & $13.27 \mathrm{e} 12.75 \mathrm{e} 12.67 \mathrm{e} 12.37 \mathrm{e} 12.12 \mathrm{e} 12.07$ \\
\hline
\end{tabular}




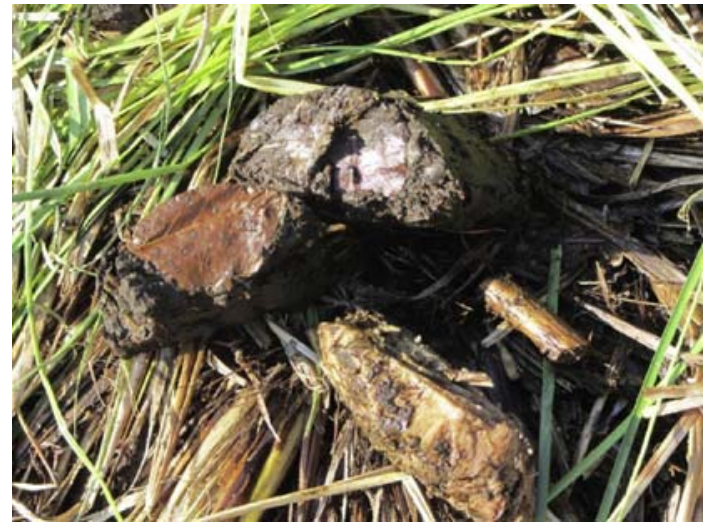

Fig. 6. Photograph of detritus gyttja at $10.50 \mathrm{~m}$ sediment depth of Trifo.11 containing beech leaves.

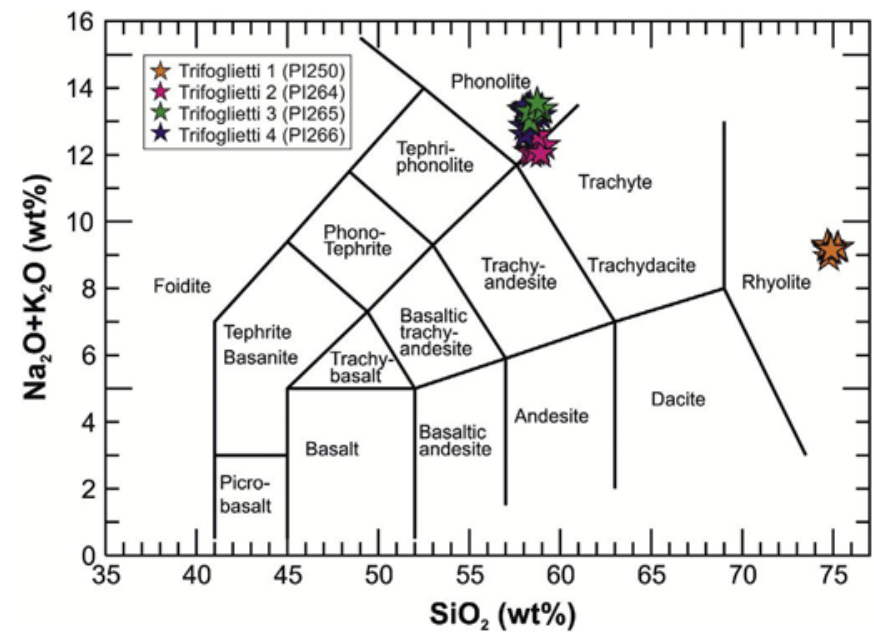

Fig. 7. Total Alkali e $\mathrm{SiO}_{2}$ diagram (Le Bas et al., 1986) for classifying tephra layers identified in the Trifoglietti core.

14.44e $45 \mathrm{~m}, 14.60 \mathrm{~m}$ and $14.77 \mathrm{e} 78 \mathrm{~m}$ composite depth and are labeled from the youngest to the oldest as Trifoglietti-1 to Trifoglietti-4, respectively.

According to the total Alkali vs SiO2 diagram (TAS diagram, Fig. 7; Le Bas et al., 1986) tephra layer Trifoglietti-1 is a rhyolite, whereas Trifoglietti-2 and -3 are phonolites (Additional informa-tion 1). Trifoglietti-4 stands along the separation between phono-lite and trachyte fields (trachyphonolite). According to the chronological and stratigraphic position of Trifoglietti-1, the cor-relation is quite straightforward: at that time only one widespread rhyolite tephra is known in the central Mediterranean and labeled by Paterne et al. (1988) as "E1-tephra". E1 is correlated with the Gabellotto/Fiumebianco activities of Lipari Island and is confirmed by comparison with other chemical data in different marine cores (Siani et al., 2004; Caron et al., 2012; Marchini et al., 2014). This tephra layer occurs within the interruption of Sapropel S1, which has been correlated with the 8.2 ka cooling event (Siani et al., 2001, 2004; Zanchetta et al., 2011). Siani et al. (2001, 2004) obtained a radiocarbon age of $7770 \pm 70{ }^{14} \mathrm{C}$ yr BP $\left(8730 \mathrm{e} 8400 \mathrm{cal}{ }^{14} \mathrm{C}\right.$ yr BP) on foraminifera from Adriatic Sea core MD 90-917 co-registered with this cryptotephra. In core MD 90-918, Caron et al. (2012) described this eruption as stratigraphically younger than the Mercato erup-tion and gave a modeled age for the E1 tephra of $8270 \pm 50 \mathrm{cal}{ }^{14} \mathrm{C} \mathrm{yr} \mathrm{BP}$, which can be used as a reference age for the chronology of the Trifoglietti sequence.

The correlation of the other three phonolitic to trachyphonolitic tephras is more problematic. Considering their chronostratigraphic position in the Trifoglietti core within the end of the Late Glacial and the K-trachytic composition with $\mathrm{K} 2 \mathrm{O} / \mathrm{Na} 2 \mathrm{O}$ ratios>2 (e.g. Smith et al., 2011 and references therein), we suggest a source of all three tephra from the Campi Flegrei. At least two violent eruptions with widespread tephra dispersal occurred during this period from the Campi Flegrei, i.e. the Neapolitan Yellow Tuff (NYT, ca 14,200 cal ${ }^{14} \mathrm{C}$ yr BP; Siani et al., 2004; Bronk Ramsey et al., 2015) and the Agnano Pomici Principali eruptions (APP, $12,037 \pm 122$ cal ${ }^{14} \mathrm{C}$ yr BP; Di Vito et al., 1999; Bronk Ramsey et al., 2015). However, those tephra are mainly dispersed towards the NE, and glass composi-tions do not match the chemical data of the Trifoglietti-2, -3 and -4 tephra layers (Fig. 8). Several other Lateglacial to early Holocene, lower-scale eruptions occurred inbetween and after these two major events, which are recorded in proximal (e.g. Smith et al., 2011; Tomlinson et al., 2012) and distal sites (e.g. Wulf et al., 2004, 2008). Comparing major element glass data of these tephra with the Trifoglietti tephra, we can observe a good match of the younger, macroscopic visible Trifoglietti-2 tephra (sample ID: PI

264) with the Soccavo 4 tephra and the distal TM-6-4c crypto-tephra from Lago Grande di Monticchio (Fig. 8). The Soccavo 4

eruption has not been directly dated yet, but is younger than the $12 \mathrm{ka}$ APP and older than the Pisani $3\left(10,635 \pm 120\right.$ cal ${ }^{14} \mathrm{C}$ yr BP; Di Vito et al., 1999) eruptions. A better age estimate is provided by the varve and sedimentation rate interpolated age of Monticchio TM-6-4c tephra at 11,980 \pm 600 varve yr BP (Wulf et al., 2008). Due to the large dating error, however, this age has not been incorpo-rated into the Trifoglietti age model. The oldest Trifoglietti4 tephra layer (sample ID: PI265) shows a similar chemical composition as the Soccavo 1 tephra and Monticchio cryptotephra TM-7-1 (12,590 \pm 630 varve yr BP; Wulf et al., 2008). The sub-Plinian Soccavo 1 eruption from the Campi Flegrei has dispersed tephra

towards the Southern Tyrrhenian Sea (Albert et al., 2012) and is well dated at 12,198 \pm 112 cal ${ }^{14} \mathrm{C}$ yr BP (Di Vito et al., 1999; Bronk Ramsey et al., 2015), therewith providing another excellent time and correlation marker. Cryptotephras Trifoglietti-3 (sample ID: PI

266) is stratigraphically younger than tephra Trifoglietti-4 and re-veals a similar glass composition. We interpret this tephra as reworked material of the primary Trifoglietti-4 tephra.

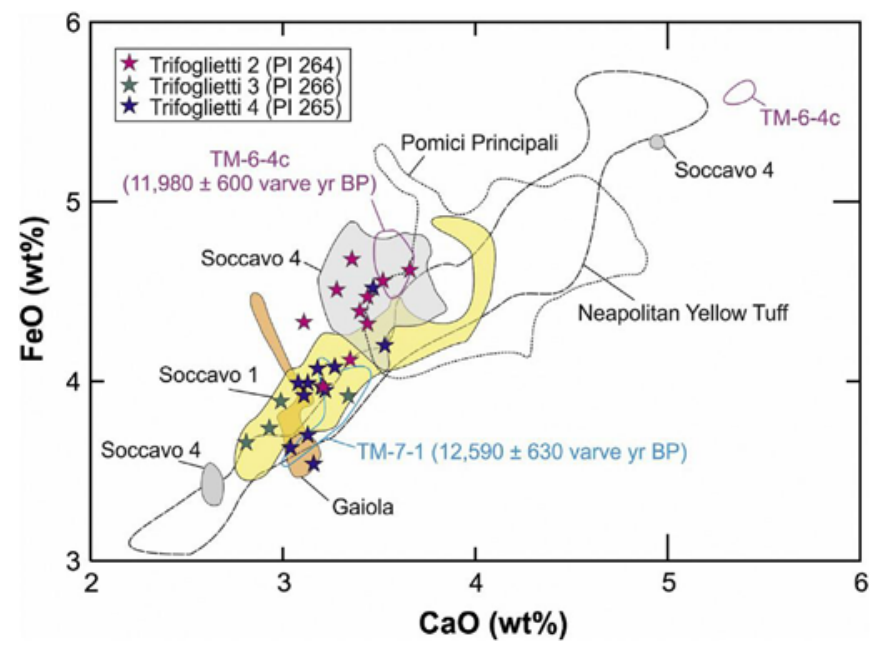

Fig. 8. Chemical bi-variate plot $\mathrm{CaO}$ versus $\mathrm{FeO}$ for discriminating phonolitic and trachyphonolitictephras from the Trifoglietti core. 


\subsubsection{Age-depth model}

The age-depth model (Fig. 3) is based on the seven calibrated ${ }^{14} \mathrm{C}$ dates of Trifoglietti organic matter and two tephra ages (E1 and Soccavo 1), while the independently-determined Monticchio varve age of the Soccavo 4 tephra is recorded on the curve. It should be noted that (1) the curve is well-constrained by the ${ }^{14} \mathrm{C}$ and tephra dates, without any reversal or stratigraphical inconsistency and (2) that the age-model overlaps the age estimate of the Soccavo 4 tephra, as defined in section 4.1.2. As a result, the chronological framework at Trifoglietti is considered robust, suggesting sedi-mentation rates between 0.4 and $1.46 \mathrm{~mm} \mathrm{yr}^{1}$ during the Late-glacial/early Holocene (Fig. 3). Furthermore, the ${ }^{14} \mathrm{C}$-based age model provides an independent age estimate for the Soccavo 4 eruptions at $11,700 \pm 150 \mathrm{cal}{ }^{14} \mathrm{C}$ yr BP, respectively.

\subsubsection{Changes in magnetic susceptibility (MS)}

Changes in magnetic susceptibility (MS) values suggest two major phases. The lower part of the sediment sequence below level $13.90 \mathrm{~m}(10,900$ cal ${ }^{14} \mathrm{C}$ yr BP) is characterized by strong variations in MS values, which reflect instability of environmental and cli-matic conditions. Two large peaks indicate the position of Late-glacial tephra layers. A third one, at $14.60 \mathrm{~m}$, corresponds to reworked Trifoglietti-3 tephra, indicating a short phase of erosion. The upper part of the sediment sequence shows low and quite constant MS values suggesting relatively stable environmental and climatic conditions in comparison to the preceding phase. The early Holocene Trifoglietti-1 tephra layer coincides with a small peak of MS values.

\subsection{The pollen record}

\subsubsection{Brief description of pollen zones}

As mentioned above, the summary pollen diagrams (Figs. 5 and 6) do not present the complete list of identified taxa, which is available on the EPD web site (http://www. europeanpollendatabase.net). The diagram is constructed using a depth scale, and the ages derived from the age/depth model appear to the left of the log. Twelve pollen assemblages zones (PAZ) from T11-1 to T11-12 are identified.

T11-1 (15.96e15.89 m; ca 14,600e14,100 cal ${ }^{14} \mathrm{C}$ yr BP): This PAZ is characterized by high NAP percentages, mostly Poaceae, Arte-misia, Plantago, Galium, Chenopodiaceae, and Rumex. Among the trees, oak is dominant. Cupressaceae (most probably Juniperus), Pinus, Abies are present, but also mesophilous taxa occur (Fraxinus, Ulmus, Tilia, Hedera).

T11-2 (15.89e15.52 m; ca 14,100e13,350 cal ${ }^{14} \mathrm{C}$ yr BP): Arboreal pollen (AP) values increase up to ca 60\% (mainly Quercus and Abies, but also Ulmus, Tilia, Corylus, Fraxinus ornus, Ostrya, and evergreen oaks). Poaceae, Artemisia and steppe elements (Ephedra) are still abundant.

T11-3 (15.52e15.03 m; ca 13,350e12,360 cal ${ }^{14} \mathrm{C}$ yr BP): There are no great changes in the pollen assemblages except for an in-crease in Rumex and monolete spores. In the upper part of the zone, a slight increase of Betula percentages is visible.

T11-4 (15.03e14.57 m; ca 12,360e 11,770 cal ${ }^{14} \mathrm{C}$ yr BP): Quercus reaches its highest percentages, whereas Juniperus, Artemisia and steppe elements are more abundant. Tilia and Ulmus are scarce.

T11-5 (14.57e14.27 m; ca 11,770e11,420 cal ${ }^{14} \mathrm{C}$ yr BP): This zone is marked by a maximum in Betula percentages. Abundances in Artemisia and Juniperus decrease.

T11-6 (14.27e14.01 m; ca 11,420e11,110 cal ${ }^{14} \mathrm{C}$ yr BP): Betula decreases, Alnus percentages increase, and Poaceae and Rumex reach their maximal values. The first occurrence of Abies stomata and a short temporary Abies maximum (toward ca.10\%) suggest some stands of this tree have approached the lake.
T11-7 (14.01e13.91 m; ca 11,110e10,945 cal ${ }^{14} \mathrm{C}$ yr BP): This zone is marked by a strong NAP increase with original assemblages including abundant Compositae, Caryophyllaceae and Heli-anthemum. A single level with a Centaurea maximum at $26 \%$ is observed.

T11-8 (13.91e13.38 m; ca 10,945e10,030 cal ${ }^{14} \mathrm{C}$ yr BP): An abrupt expansion of mountain trees (Fagus and Abies) occurs above $13.75 \mathrm{~m}$. Abies stomata are regularly present, while Ostrya shows the beginning of a continuous curve. Among various NAP, Poaceae are the only taxa with percentages that remain high (around $10 \%$ ).

T11-9 (13.38e13.32 m; ca 10,030e9950 cal ${ }^{14} \mathrm{C}$ yr BP): This is a short zone marked by a decrease in Quercus percentages to the benefit of Fagus.

T11-10 (13.32e13.11 m; ca 9950e9600 cal ${ }^{14} \mathrm{C}$ yr BP): Fagus and AP recede, and Quercus stabilizes around $20 \%$. Ostrya percentages attain a maximum value above $10 \%$. Taxus pollen is present.

T11-11 (13.11e12.58 m; ca 9600-8915 cal ${ }^{14} \mathrm{C}$ yr BP): Quercus percentages decline to ca $10 \%$, while Ulmus is more abundant.

T11-12 (12.58e11.10 m; ca 8915-7590 cal ${ }^{14} \mathrm{C}$ yr BP): Ulmus de-clines, and Osmunda starts its expansion. Above $12 \mathrm{~m}$, less abun-dant Poaceae could identify a subzone.

\subsubsection{Rare pollen taxa}

Beside the set of abundant pollen grains whose variations determine the succession of zones they are rare pollen taxa (Table 2) whose present ecology may contribute to refine the un-derstanding of the past landscapes. An exploration of this present ecology and distribution in Calabria and around is given in on-line Additional information 2. We can already distinguish two series of taxa. The first occurs in the lower part of the sequence (from T11-1 to T11-7) and includes Arcetobium oxycedri, Calligonum, Cerinthe, Daphne, Cynoglossum/ Anchusa, Epilobium, Euphorbia, Gentiana and Gentianella, Linum, Pinguicula, and Theligonum cynocrambe and the second above T11-7 and encompasses the following taxa: Chei-lanthes, Cladium, Erica terminalis, Lysimachia, Polypodium, and Vitis vinifera. This distribution is linked with the change from clay-gyttja to detritus gyttja.

\section{Discussion}

\subsection{An attempt to combine age-depth model, sediments changes and vegetation dynamics}

\subsubsection{Chronological framework}

According to the Trifoglietti age model (Fig. 3), the vegetation dynamics reflected in the pollen diagram can be easily related to climate events defined elsewhere in Southwest Europe (Beaulieu et al., 2005). If we follow the chronological framework proposed in Fig. 4, PAZ T11-1, with a rather high amount of steppe elements, corresponds to the Oldest Dryas/LGI transition. PAZ T11-2 and a part of PAZ T11-3 correspond to the LGI; the upper part of PAZ T11-3 and PAZ T11-4 coincides with the Younger Dryas (YD). Here we consider the YD as a chronozone and accept the age of respectively 12,850 ${ }^{14} \mathrm{C}$ cal BP and $11,700{ }^{14} \mathrm{C}$ cal BP for its beginning and its end, following the Greenland ice cores chronology (Rasmussen et al., 2006). It is the reason why the YD lower limit does not exactly coincide with the T11-3/T11-4 boundary. This discrepancy cannot be used to suggest that the YD cooling may be time transgressive due to the imprecision of the present Trifoglietti age model.

The early Holocene which starts with the expansion of Betula in PAZ T11-5; PAZ T11-6 will be discussed below. The PAZ T11-7 to T11-12 may be correlated with the lower part of the pollen sequence Trifo.09, already published by Joannin et al. (2012).

The correlation between Trifo. 11 and Trifo.09 is based on MS, ${ }^{14} \mathrm{C}$ dates and pollen assemblages (Fig. 3). PAZ T11-7, with abundant 
NAP just before the setting of the beech-fir forest is identical to PAZ T09.2 in Joannin et al. (2012), well dated by three ${ }^{14} \mathrm{C}$ ages (Table 1). This common interval can be clearly correlated with the Preboreal Oscillation (PBO) whose age is fixed at $11,350 \mathrm{e} 11,150 \mathrm{cal}{ }^{14} \mathrm{C}$ yr BP (Mayewski et al., 2004). In addition, the MS curve (Fig. 3) may contribute to refine this chronology: here we assume that periods with a higher susceptibility reflecting high terrigenous influx and/ or lower biogenic productivity in the lake are due to periods of cooling with decreasing vegetation cover (the susceptibility peaks due to tephra layers are excluded). Thus, the high MS values at the base of the sequence are in agreement with the attribution to the end of Oldest Dryas. The following drop in susceptibility corre-sponds to an increase in arboreal pollen ratio, but immediately after, a second maximum is linked with a decline in AP percentages (mostly Abies): this short event, not identified as a pollen zone, could correspond to the Aegelsee oscillation (Lotter et al., 1992) at ca 13,960 cal ${ }^{14} \mathrm{C}$ yr BP in good agreement with the Trifoglietti age model. After a progressive decline in AP pollen toward a minimum at $15.35 \mathrm{~m}$, a new maximum occurs between $15.30 \mathrm{~m}$ and $15.17 \mathrm{~m}$ : this event occurring in the middle part of PAZ T11-3 is not marked by any clear change in the pollen assemblage, but could correspond to the Gerzensee oscillation at ca 13,030 cal ${ }^{14} \mathrm{C}$ yr BP (Van Raden et al., 2013). This hypothesis remains within the error bars of the Trifoglietti age model. Moreover, following the MS peak at $15.17 \mathrm{e} 14.94 \mathrm{~m}$, the very low MS value is in agreement with an attribution of the upper part of PAZ T11-3 to the end of the LGI. A new increase in MS values at $14.94 \mathrm{~m}$, coinciding with a clear lithological change is the signature of the starting YD slightly above the PAZ T11-3/T11-4 transition. Thus, along the Lateglacial/Holo-cene transition, the data obtained from the Trifoglietti sediment sequence suggest that the MS appears to have been generally more sensitive to short term (secular) climate oscillations than pollen data.

\subsubsection{The Lateglacial interstadial}

All along the LGI, the arboreal pollen percentages are stabilized between $50 \%$ and $60 \%$, suggesting the site to be not very far from the timberline under an open landscape. The most abundant tree pollen types are deciduous oaks and fir. Among deciduous oak pollen grains we can assume that Quercus cerris woodstands were present at lower latitude at least since the LGI. If we refer to the Abies pollen rains nowadays (Joannin et al., 2012), the percentages of this tree (up to 25\% in PAZ T11-2) suggest that it could be present in the immediate vicinity of the lake, but the absence of macroremains and stomata lead us to propose scattered stands in the surrounding, or populations on the mountain slopes at lower altitude.

Another characteristic of the Lateglacial pollen spectra is the occurrence of a large panel of mesophillous arboreal taxa: the whole elements of the "Quercetum mixtum", Fraxinus ornus, Fagus whose occurrences increase during T11.3. Mediterranean xero-phytic taxa are also present but with low percentages suggesting that they were restricted to a thin zone near the coast. This diversity reflects an original status of the Catena Costiera (middle mountain range characterized by high precipitation rates) as a refugial zone, which is conforming to the model proposed by Beug (1976). The quasi absence of Pinus is surprising: Pinus nigra subsp. laricio is nowadays very common on the Sila Massif, not far from the Trifo-glietti lake, while scattered populations of Pinus heldreichii var. leucodermis, growing on the Pollino mountain chain, are considered as the relicts of larger forests. Here, their absence could be due to an unfavorable substratum. Among the occasional taxa, Cedrus pollen grains are identified several times during the LGI (and the upper part of the YD): they correspond to distant transport from North Africa; a pollen grain of Calligonum (T11-2), a sub-Saharan taxon, confirm this transport by winds from Africa, observed elsewhere in Lateglacial records from south Europe (Beaulieu, 1977) even if the juniper percentages are low. Among NAP, Poaceae and Rumex are the more abundant, suggesting an environment with subalpine meadows; a pollen grain of Arcetobium oxycedri (T11-2), parasitic on Juniperus also testifies on the local presence of shrub stands around the lake. NAP taxa are extremely diverse: beside steppe elements there are also taxa that are characteristic for wet meadows (Filipendula, Sanguisorba officinalis, Lysimachia). Mono-lete spores that are abundant during the LGI also suggest wet and shady surrounding. This rare juxtaposition may be explained by the particular topography of the slopes surrounding Lago Trifoglietti. They are most probably formed by a huge landslide generating closed depressions, hillocks and rock chaos that are favorable for various ecological niches. Such a landscape may have contributed to preserve the biodiversity during the Last Glacial Maximum.

\subsubsection{The younger dryas}

A surprise comes from the YD which shows, in the present Trifoglietti age model, beside the moderate increase of steppe taxa, a marked maximum in Quercus percentages. It could correspond to a resilient dynamic: the climate evolution during the LGI allowing a late expansion of Quercus that was not affected by the YD cooling. As a matter of facts, the increase in Quercus \% slightly predates the expansion of steppe elements. But this increase is not valid for the other temperate elements, which are less abundant. In any case, the YD does not appear at Trifoglietti as a major paleoecological crisis contrary to what is evidenced in higher latitudes (e.g. Joannin et al., 2013). A dense oak forest is questioned as monolete spores decrease during the YD suggests less wet and shady conditions in the surrounding than during the LGI. Several occurrences of Cedrus pollen are observed at the end of YD: this concentration could be linked with a specific wind regime (Magri and Parra, 2002).

\subsubsection{The early Holocene}

In agreement with the age model, the YD/Holocene boundary occurs at the PAZ T11-4/T11-5 transition. PAZ T11-5 is characterized by a wellmarked phase of Betula expansion. Most probably this tree, previously discreet, colonizes the lake margin. It suggests either wetter conditions or a lowering of the lake water level; we prefer the second hypothesis which could induce an extension of terrigenous influx over the lake-basin margins, responsible for both a high MS value and a development of Betula overlapping the YD-Holocene transition. This success could be also related to an in-crease in spring temperature that encourages the development of inflorescences and pollen. Moreover, the fact that the occurrences of Artemisia remain at the same level as during the YD suggests a still relatively dry climate. The early Holocene (PAZ T11-6) is not at all characterized by the setting of forests, classical elsewhere at the same altitude as Lago Trifoglietti (see below, section 5.2: Trifoglietti among other Lateglacial Italian records). Here the regression of steppe taxa to the benefit of other NAP, mainly Poaceae, Rumex and monolete spores suggests an expansion of meadows; nevertheless in the middle of this zone a slight increase in Abies percentages and the first occurrence of Abies stomata imply that fir trees approache the site. This surprising supra-sylvatic status was stable for ca. 500 years. Anyway, the progressive decrease in values of MS during the pollen zones T11-5 and T11-6 probably reflects a development of the vegetation cover favored by the climate warming prevailing during the early Holocene.

\subsubsection{The Preboreal oscillation: "Trifoglietti event"}

The stable period was interrupted by an abrupt event, the so-called here "Trifoglietti event" (T11-7), already observed at the base of the previous core (T.09: 11,500e11,200 cal ${ }^{14} \mathrm{C}$ yr BP; Joannin 
et al., 2012). The AP percentages decrease to less than $40 \%$, Poaceae and Rumex are drastically reduced to the benefits of a rare assem-blage of various Caryophyllaceae, Cichorioideae, Asteroideae and Centaurea (whose percentages rise up to $26 \%$ in one sample sug-gesting either a taphonomic disturbance or a brief drying up of the lake), which are typical for dry meadows. The very high amount of micro-charcoals observed in the pollen slides and the occurrence of the NPP Gelasinospora attest local fires (a detailed Micro-charcoal study is in progress). This "Trifoglietti event", centered on $11,000 \mathrm{cal}{ }^{14} \mathrm{C}$ yr BP, has been related to the PBO (Joannin et al., 2012) and likely corresponds to an episode of climate drying that is responsible for forest fires and the quite original vegetation observed here. The origin of the PBO event, first described in Northern Germany (Behre, 1967, 1978) has been long debated. Bjorck€ et al. (1997) identified it as a cold and humid oscillation due to a change in the North Atlantic circulation, while Van der Plicht et al. (2004) describe the same event as dry and cool and due to a decline in the solar activity. It is rather difficult to identify the PBO event in pollen records from middle Europe, and it is thus a surprise to observe such an event so well marked in Southern Italy: its impact could have been accentuated under a Mediterranean regime and by local conditions (steep slopes in the catchment favoring runoff and detritic influx to the lake during periods of decreasing vegetation cover exacerbated by forest fires).

The enhanced sensitivity of Trifoglietti record compared to other southern records (Accesa, Magny et al., 2007; Valle di Diano, Di Rita et al., 2013) emphasizes the importance of being close to the moving timberline.

\subsubsection{A late forest setting}

Immediately after the PBO crisis, the Fagus and Abies percentage abruptly increase showing the quick setting of a beech-fir forest around the lake. This is confirmed by (1) the change of the type of sediments from organic-rich toward detritus gyttja, (2) the regular occurrence of Abies stomata and of the NPP Asterosporium (a beech parasite: Cugny, 2011), and (3) a marked increase in the AP per-centages from a median value of ca $50 / 60 \%$ characteristic for the period $14,000 \mathrm{e} 11,000 \mathrm{cal}{ }^{14} \mathrm{C}$ yr BP to values of ca $80 / 90 \%$ charac-teristic for the Holocene after 11,000 cal ${ }^{14} \mathrm{C}$ yr BP. Some occur-rences of pollen grains of Cladium, nowadays surviving at lower altitude in Calabria, and of Vitis give evidence of a warmer climate.

Above $13.90 \mathrm{~m}$, the Holocene pollen data of Trifoglietti 2011 is coherent with the already published data of Trifoglietti 2009: PAZ T11-8-9-10 clearly corresponds to T-3a in Trifo.09 (the event identified in PAZ T11-9 is not recorded in Trifo.09). The same regression of oaks to the benefit of Fagus and Abies at $13.12 \mathrm{~m}$ (Trifo.11) and $7.15 \mathrm{~m}$ (Trifo.09) suggests a denser local cover by the beech/fir forest. In both sequences the disappearance of Botryococcus and the expansion of Osmunda regalis at ca. $9000 \mathrm{cal}{ }^{14} \mathrm{C}$ yr BP (at the end of PAZ T11-11 in Trifo.11 and T-3c in Trifo.09 respectively) correspond to the reduction of open water to the benefit of a swamp progressively invaded by this fern.

\subsection{Trifoglietti among other Lateglacial Italian records}

Several Italian sites provide vegetation records of the Lateglacial/Holocene transition. Most of them comes from long sequences from crater lakes in central Italy (lakes Albano and Niemi: Lowe et al., 1996; Asioli et al., 1999; Valle di Castiglione, Stracciacappa: Follieri et al., 1998; Lago di Vico: Magri and Sadori, 1999; Lagac-cione: Magri, 1999). For some of those records a detailed study of the Lateglacial was not a priority, so that absolute dating and sampling resolution are not sufficient to allow precise correlations. Nevertheless common trends appear in the vegetation dynamics, i.e. (1) a more or less marked expansion of mesophilous trees at the beginning of the LGI: Quercus robur t., Corylus and, less abundant, Tilia and Ulmus, (2) a regression of trees to the benefits of steppe taxa from lowland to middle mountains, and (3) a re-expansion of tree taxa after the YD. This general trend is also reported in Sadori (2013). A detailed analysis, however, shows that the vegetation changes are quite diverse, suggesting a possible interplay between different climate forcing or locally different answers to climatic change.

The only pollen sequences from sites at mountain altitude similar to Trifoglietti are those of the Parmesan Apennines in $700 \mathrm{~km}$ distance to the North: Lagdei (Bertoldi, 1980; Bertoldi et al., 2007), Prato-Spilla (Ponel and Lowe, 1992; Lowe, 1992) and adja-cent sites (Lowe and Watson, 1993; Watson, 1996). A great differ-ence is the major role played by Pinus during the LGI in the Parmesan Apennines, as in the Alps; a similarity is the Lateglacial expansion of Abies (while Fagus is absent and will expand latter during the mid-Holocene). Lagdei registers a presence of Abies during the temperate episodes of the last Pleniglacial, in agreement with the long records from crater lakes (Follieri et al., 1998; Allen et al., 2000): they illustrate the role of refugial zone played by the Apennines from North to South.

The mountain sites are not the only ones showing a poor Late-glacial forest recovery: to the $\mathrm{N}-\mathrm{W}$ of the Apennines, in the "Euganean hills", at Lago della Costa (7 m a.s.l.) (Kaltenrieder et al., 2010), open vegetation (Pinus, Quercus robur t., Corylus, more than 50\% NAP) persists from the beginning of the LGI to ca $9500 \mathrm{cal}{ }^{14} \mathrm{C}$ yr BP. At Lago dell'Accesa (DrescherSchneider et al., 2007), even if the LGI is marked by an expansion of deciduous oaks, the AP\% stand also at ca $50 \%$ and decrease to ca $20 \%$ during the YD. There, as well as at Stracciacappa (Giardini, 2007) a hiatus occurs at the end of the YD (suggesting a low lake level) followed by an abrupt expansion of mixed oak forest.

To the south, at Valle di Castiglione (44 m a.s.l.), Di Rita et al. (2013) provided a new high-resolution pollen study of the Late-glacial/Holocene transition. The LGI is characterized by a moderate expansion of Mediterranean (Quercus ilex t.) and mesophilous trees whereas Chenopodiaceae attest a still arid climate. The YD is clas-sically marked by an Artemisia maximum. An original feature here is a double Chenopodiaceae maximum: the first at the $\mathrm{YD} /$ Holocene boundary followed by a moderate expansion of oaks and abruptly stopped by the second maximum. The authors attribute this second dry episode to the PBO (already described at Accesa where this event is quite discrete (Magny et al., 2007)). At Valle di Castiglione a major expansion of forest elements (including Fagus) is dated at ca $11,000 \mathrm{cal}{ }^{14} \mathrm{C}$ yr BP, i.e. 700 years after the onset of the Holocene (in several sites in the hill stage of central Italy, beech may start its expansion during the early Holocene: at ca $10,300 \mathrm{cal}{ }^{14} \mathrm{C}$ yr BP at Lago di Vico for instance). This well radiocarbon-dated sediment sequence presents a robust chronology and differs from the bioclimatic schemes classical to the North of Italy. Similar delays in the Holocene forest setting have also been evidenced in Sicily where they are strongly marked. At Lago di Pergusa (Sadori and Narcisi, 2001; Sadori et al., 2008) deciduous oak wood stands settled progressively (together with Quercus ilex) till an optimum at ca 10,000 cal ${ }^{14} \mathrm{C}$ yr BP. Similar temperate tree developments are observed in marine core MD04-2797CQ from the Siculo-Tunisian Strait (Desprat et al., 2013) while marine core MD 90-917, receiving pollen from both Italy and Balkans, already shows temperate forest establishment at the $\mathrm{YD} /$ Holocene transition (Siani et al., 2013; Combourieu-Nebout et al., 2013).

Finally, the closest reference for comparisons with Trifoglietti is Lago Grande di Monticchio (Basilicata, $656 \mathrm{~m}$ a.s.l.). This crater lake has been deeply explored since 1985 (e.g., Watts et al., 1996; Brauer et al., 2007). An article concentrates on the Lateglacial (Huntley et al., 1999) and the most recent pollen study on this interval 
(Allen et al., 2002) at a high resolution is supported by robust chronologies $\left({ }^{14} \mathrm{C}\right.$, annual lamination counts, tephrochronology). But the key tools for correlation with Trifoglietti are the tephra layers Soccavo 1 and Soccavo 4 observed respectively at 8.10 and $7.73 \mathrm{~m}$ depth. Here, the beginning of the LGI, not observed at Tri-foglietti is marked by an abrupt decline of abundant Artemisia and Cupressaceae. During the LGI (PAZ 3), Betula expands; Quercus t. robur frequencies progressively increase toward high values (ca $60 \%$ ) culminating together with a Tilia maximum: the "Quercetum mixtum" is close to the lake. A continuous curve of Fagus suggests a regional presence, and Abies is absent. The Soccavo 1 tephra layer is observed after the beginning of PAZ 2, correlated with the YD. It occurs, as at Trifoglietti, after a slight increase of Artemisia. In both sites Soccavo 4 tephra layer is contemporaneous with a last Betula maximum corresponding to the end of the YD. But at Monticchio, Allen et al., following the CONISS ordination, include the upper part of zone 2 in a "Lateglacial" ending at $11.200 \mathrm{cal} \mathrm{C14} \mathrm{yr}$ BP. This in-terval corresponds to PAZ T11-6 at Trifoglietti, attributed to the early Preboreal. In both cases it is marked by the persistence on a good number of NAP and shows a delay in the maturity of diver-sified mesic forest in the hill stage and in the local expansion of the beech-fir forest at Trifoglietti. Allen et al. (2002) propose a climate reconstruction which shows similar low MTCO (mean temperature of the coldest month) and AET/PET (ratio of actual to potential evapotranspiration) during the YD and the early Preboreal. But the great discrepancy between Trifoglietti and Monticchio is that not any signal of a PBO is observed at Monticchio.

\section{Conclusion}

The new core from Lago Trifoglietti brings a harvest of infor-mation, which constitutes a valuable complement to a series of new investigations on the Italian peninsula and in Sicily.

As mentioned in the introduction section, Lago Trifoglietti is a rare site in Southern Italy providing a pollen record at the altitude of the mountain stage (together with Urio Quattrocchi, Sicily, $1000 \mathrm{~m}$ a.s.l., Bisculm et al., 2012, which documents the Holocene). Due to this location, it reveals unique and quite original Lateglacial vegetation dynamic.

This pollen record confirms the role of South Italian Mountains as refuge for temperate species during the Pleistocene. As already mentioned by Joannin et al. (2012), Trifoglietti is also a rare example of a beech-fir forest ecosystem which is remarkably stable for eleven millennia; but this local climax does not mean that this Calabrian population is at the origin of an Holocene expansion to-ward the north: studies on the phylogeography of Abies (Lipietz et al., 2008) and Fagus (Vettori et al., 2004; Magri et al., 2006) demonstrate that they remained isolated in their refuge zone. They did not succeed to mate with more northern populations even if their ecological potential allowed them to withdraw from Calabria (Tinner et al., 2013). The occurrence of a pollen grain of Erica ter-minalis, an endemic taxon growing nowadays not far from Trifo-glietti in a locality of south Campania and in Corsica (Spada et al., 2010), illustrates also a long Pleistocene survival. Thus South Italy,

identified as a hotspot of biodiversity (Quezel and Medail, 2003) must be considered as a botanical conservatory more than as a classical refugial zone.

Surprisingly, beside the moderate increase of steppe taxa, the Younger Dryas is not marked by major changes, and oak percent-ages are even higher, suggesting a resilient expansion at lower altitude, confirmed at Monticchio.

One of the goals of this study was also to validate a well-marked dry event observed at the basis of the previous core Trifo.09 (Joannin et al., 2012), as a local expression of the Preboreal oscil-lation (PBO). The demonstration is now robust. As a matter of fact, this event, in Calabria as well as in the Latium (Di Rita et al., 2013) represents the real transition from poorly forested "Lateglacial style" vegetation to the forested ecosystems of the Middle Holo-cene. Here, the high-resolution record of the Lateglacial illustrates a permanent status above but not very far from the timberline from $14,300 \mathrm{cal}{ }^{14} \mathrm{C}$ yr BP to $11,000 \mathrm{cal}$ ${ }^{14} \mathrm{C}$ yr BP. This is in agreement with the dominance of an oak forest in the hill stage as illustrated by the pollen record of Lago Grande di Monticchio where an oak forest was already present before the YD.

Nevertheless the reason why the warming occurring at the YD/ Holocene transition did not allow a rise of the forest line above the altitude of Trifoglietti remains unclear. The argument of a persistent aridity used to explain a delay in the forests expansion at low altitude in Sicily and Latium cannot be applied to Trifoglietti where annual precipitation today is extremely high. A multi-proxy approach (NPP, micro-charcoals, chironomids, quantitative climate reconstructions) is in preparation with the goal to better identify the bioclimatic forcing of this early Holocene lag in reforestation.

Finally, another issue of this multidisciplinary study is that the age model provided by the ${ }^{14} \mathrm{C}$ dating of the Trifoglietti sequence may contribute to better constrain the chronology of some Late-glacial volcanic eruptions in the Campi Flegrei and, in return, bring once again the demonstration that the identification of tephra layers in sedimentary sequences constitutes a precious chrono-logical tool.

\section{Acknowledgments}

This study is a late result of the project LAMA (M. Magny and N. Combourieu-Nebout) supported by the French ANR. We are grateful to the authorities of the city of Fagnano Castello for their interest and support during the coring, in particular Dr. Gallo Marcellino, Assessore all'Ambiente del Comune, Bianco Pierangelo and Bianco Pantaleo. We sincerely thank two anonymous reviewers for their constructive remarks.

We dedicate this text to Pierre Quezel, the unrivalled Mediter-ranean botanist, who left us on the 21 of October 2015.

\section{Appendix A. Supplementary data}

Supplementary data related to this article can be found at http:// dx.doi.org/10.1016/j.quascirev.2016.12.013.

\section{References}

Albert, P.G., Tomlinson, E.L., Smith, V.C., Roberto, D.A., Todman, A., Rosi, M., Marani, M., Muller, W., Menzies, M.A., 2012. Marine-continental tephra corre-lations: volcanic glass geochemistry from the Marsili Basin and the Aeolian Islands, Southern Tyrrhenian Sea, Italy. J. Volcanol. Geotherm. Res. 229e230, 74e94.

Allen, J.R.M., Watts, W.A., McGee, E., Huntley, B., 2002. Holocene environmental variabilityethe record from Lago Grande di Monticchio, Italy. Quat. Int. 88, 69e80.

Allen, J.R.M., Watts, W.A., Huntley, B., 2000. Weichselian palynostratigraphy palaeovegetation and palaeoenvironment; the record from Lago Grande di Monticchio, southern Italy, Quat. Int. 73/74, 91e110.

Amodio-Morelli, L., Bonardi, G., Colonna, V., Dietrich, D., Giunta, G., Ippolito, F., Liguori, V., Lorenzoni, S., Paglionico, A., Perrone, V., Piccaretta, G., Russo, M., Scandone, P., Zanettin Lorenzoni, E., Zuppetta, A., 1976. L'Arco calabro-peloritano nell'orogene appenninicomaghrebide. Mem. Soc. Geol. Ital. 17, 1e60.

Asioli, A., Trincardi, F., Lowe, J.J., Oldfield, F., 1999. Short-term climate changes during the Last GlacialeHolocene transition: comparison between Mediterra-nean records and the GRIP event stratigraphy. J. Quat. Sci. 14 (4), 373e381.

Beaulieu, J.-L. de, 1977. Contribution pollenanalytique a l'histoire tardiglaciaire et holocene de la vegetation des Alpes meridionales françaises (These es Sciences, Marseille).

Beaulieu, J.-L. de, Miras, Y., Andrieu-Ponel, V., Guiter, F., 2005. Vegetation dynamics in north-western Mediterranean regions: instability of the Mediterranean bioclimates. Plant Biosyst. 139 (2), 114e126. 
Behre, K.E., 1967. The Late Glacial and Early Postglacial history of vegetationand climate in northwestern Germany. Rev. Palaeobot. Palynol. 4, 149e161.

Behre, K.E., 1978. Climatic oscillations in European Preboreal. Petermanns Geogr. Mittl. 122 (2), 97e102.

Bertoldi, R., 1980. Le vicende vegetazionali e climatiche nella sequenza paleo-botanica würmina e post-würmiana di Lagdei (Appennino settentrionale). Acta Nat. Ateneo Parm. $18,147 \mathrm{e} 175$.

Bertoldi, R., Chelli, A., Roma, R., Tellini, C., 2007. New data from Northern Apennines (Italy) pollen sequences spanning the last 30,000 yrs. Il Quat. Italian J. Quat. Sci. 20 (1), 3e20.

Beug, H.J., 1976. Probleme der Vegetationsgeschichte in Südeuropa. Ber. Dtsch. Bot. Gesellsc. 80 (10), 682e689.

Beug, H.J., 2004. Leitfaden der Pollenbestimmung für Mitteleuropa und angren-zende Gebeite Pfeil, München.

Bisculm, M. Colombaroli, D., Vescovi, E., van Leeuwen, J.F.N., Henne, P., Rothen, J., Procacci, G., Pasta, S., La Mantia, T., Tinner, W., 2012. Holocene vegetation and fire dynamics in the supra-mediterranean belt of the Nebrodi Mountains (Sicily, Italy). J. Quat. Sci. 27 (7), 687e698.

Bjorck,€ S., Rundgren, M., Ingolfsson, O., Funder, S., 1997. The Preboreal oscillation around the Nordic Seas: terrestrial and lacustrine responses. J. Quat. Sci. 12, 455 e465.

Blaauw, M., 2010. Methods and code for "classical" age-modelling of radiocarbon sequences Quat. Geochronol. 5, 512e518.

Blasi, C., Michetti, L., 2007. The climate of Italy. In: Blasi, C., Boitani, L., La Posta, S., Manes, F., Marchetti, M. (Eds.), Biodiversity in Italy. Palombi Editori, Roma, pp. 57e66.

Brauer, A., Allen, J.R.M., Minjram, J., Dulsk, P., Wulf, S., Huntley, B., 2007. Evidence for las Interglacial chronology and environmental change from Southern Europe. PNAS 104 (2), $450 \mathrm{e} 455$.

Bronk Ramsey, C., Albert, P.G., Blockley, S.P.E., Hardiman, M., Housley, R.A., Lane, C.S., Lee, S., Matthews, I.P., Smith, V., Lowe, J., 2015. Improved age estimates for key Late Quaternary European tephra horizons in the RESET lattice. Quat. Sci. Rev. 118, $18 \mathrm{e} 32$.

Caron, B., Sulpizio, R., Zanchetta, G., Siani, G., Santacroce, R., 2010. The Late Holo-cene to Pleistocene tephrostratigraphic record of lake Orhid (Albania). Comptes Rendus Geosci. $342,453 \mathrm{e} 466$.

Caron, B., Siani, G., Sulpizio, R., Zanchetta, G., Paterne, M., Santacroce, R., Tema, E., Zanella, E., 2012. Late Pleistocene to Holocene tephrostratigraphic record from the Northern Ionia Sea. Mar. Geol. 311e314, 41e51.

Ciancio, O., 1971. Sul clima e sulla distribuzione altimetrica della vegetazione forestale in Calabria. In: Annali dell'Istituto Sperimentale per la Selvicoltura. II, pp. 321e370.

Cioni, R., Marianelli, P., Santacroce, R., 1997. Thermal and compositional evolution of the shallow magma chambers of Vesuvius: evidence from pyroxene pheno-crysts and melt inclusions. J. Geophys. Res. 103, 18277e18294.

Combourieu-Nebout, N., Peyron, O., Bout-Roumazeilles, V., Goring, S., Dormoy, I., Joannin, S., Sadori, L., Siani, G., Magny, M., 2013. Holocene vegetation and climate changes in central Mediterranean inferred from a high-resolution marine pollen record (Adriatic Sea). Clim. Past 9, 2023e2042.

Cugny, C., 2011. Apports des microfossiles non-polliniques a l'histoire du pastoralisme sur le versant nord Pyreneen : entre referentiels actuels et reconstitution du passe (These). Universite de Toulouse.

Desprat, S., Combourieu-Nebout, N., Essallami, L., Sicre, M.A., Dormoy, I., Peyron, O., Siani, G., Bout Roumazeilles, V., Turon, J.L., 2013. Deglacial and Holocene vegetation and climatic changes in the southern Central Mediterranean from a direct land-sea correlation. Clim. Past 9, 767e787.

Di Rita, F., Anzidei, A.P., Magri, D., 2013. A Lateglacial and early Holocene pollen record from Valle di Castiglione (Rome): vegetation dynamics and climate implications. Quat. Int. 288, $73 \mathrm{e} 80$.

Di Vito, M.A., Isaia, R., Orsi, G., Southon, J., De Vita, S., D'Antonio, M., Pappalardo, L., Piochi, M., 1999. Volcanism and deformation since 12,000 years at the Campi Flegrei caldera (Italy). J. Volcanol. Geotherm. Res. 91, 221e246.

Drescher-Schneider, R., Beaulieu, J.-L. de., Magny, M., Walter-Simonnet, A., Bossuet, G., Millet, L., Brugiapaglia, E., Drescher, A., 2007. Vegetation history, climate and human impact over the last 15,000 years at Lago dell'Accesa (Tuscany, Central Italy). Veg. Hist. Archaeobot. 16, 279e299.

Follieri, M., Giardini, M., Magri, D., Sadori, L., 1998. Palynostratigraphy of the last glacial period in the volcanic region of central Italy. Quat. Int. 47e48, 3e20.

Gedye, S.J., Jones, R.T., Tinner, W., Ammann, B., Oldfield, F., 2000. The use of minera magnetism in the reconstruction of fire history: a case study from Lago di Origlio, Swis Alps. Palaeogeogr. Palaeoclimatol. Palaeoecol. 164, 101e110.

Giardini, M., 2007. Late quaternary vegetation history at Stracciacappa (Rome, Italy). Veg. Hist. Archaeobot. 16, 301e316.

Grimm, E.C., 1987. CONISS: a FORTRAN 77 program for stratigraphically constrained cluste analysis by the method of incremental sum of squares. Comput. Geosci. 13 (1), 13 e35.

Hewitt, G.M., 2011. Mediterranean Peninsulas - the evolution of hotspots. In: Zachos, F.E., Habel, J.C. (Eds.), Biodiversity Hotspots. Springer, Heidelberg, pp. $123 e 147$.

Hunt, J.B., Hill, P.G., 2001. Tephrological implications of beam size-sample-size ef-fects in electron microprobe analysis of glass shards. J. Quat. Sci. 16, $105 \mathrm{e} 117$.

Huntley, B., Watts, W.A., Allen, J.R.M., Zolitschka, B., 1999. Palaeoclimate, chronology and vegetation histoty of the Weichselian Lateglacial: comparative analysis of data from three cores at Lagi Grande di Monticchio, southern Italy. Quat. Sci. Rev. 18, 945 e960.
Joannin, S., Vanniere, B., Galop, D., Peyron, O., Haas, J.N., Gilli, A., Chapron, E., Wirth, S. Anselmetti, F., Desmet, M., Magny, M., 2013. Climate and vegetation changes during the Lateglacial and early-middle Holocene at Lake Ledro (southern Alps, Italy). Clim. Past 9, 913e933.

Joannin, S., Brugiapaglia, E., Beaulieu, J.-L. de, Bernardo, L., Magny, M., Peyron, O., Goring, S., Vanniere, B., 2012. Pollen-based reconstruction of Holocene vege-tation and climate in southern Italy: the case of Lago di Trifoglietti. In: Special Issue: Holocene Changes in Environment and Climate in the Central Mediter-ranean as Reflected by Lake and Marine Records. Climate of the Past, vol. 8, pp. $1973 \mathrm{e} 1996$.

Jong, E.D., Nestor, P.A., Pennock, D.J., 1998. The use of magnetic susceptibility to measure long-term soil redistribution. Catena 32, 23 e35.

Juggins, S., 2007. C2: Software for Ecological and Palaeoecological Data Analysis and Visualisation (User Guide Version 1.5). Newcastle University, Newcastle upon Tyne, 77 pp.

Juggins, S., 2012. Rioja: Analysis of Quaternary Science Data (R Package Version (0.8-5)).

Kaltenrieder, P., Procacci, G., Vanniere, B., Tinner, W., 2010. Vegetation and fire history of the Euganean Hills (Colli Euganei) as recorded by Lateglacial and Holocene sedimentary series from Lago della Costa (northeastern Italy). Holo-cene 20 (5), 679e695.

Le Bas, M.J., Le Maitre, R.W., Streckheisen, A., Zanettin, B., 1986. Chemical classifi-cation of volcanic rocks based on the total alkali-silica diagram. J. Petrol. 27, 745e750.

Lipietz, S., Cheddadi, R., Beaulieu, J.-L.de, Fady, B., Gom€ory,€ D., Hussendorfer, € E. Konnert, M., Litt, T., Longauer, R., Terhürne-Benson, R., Ziegenhagen, B., 2008. Postglacial range expansion and its genetic imprints in Abies alba (Mill.) e a synthesis from palaeobotanic and genetic data. Rev. Palaeobot. Palynol. 153, 139e149.

Lotter, A.F., Eicher, U., Siegenthaler, U., Birks, H.J.B., 1992. Late-glacial climatic os-cillations as recorded in Swiss lake sediments. J. Quat. Sci. 7, 187e204.

Lowe, J.J., 1992. Lateglacial and early Holocene lake sediments from the northern Apennines, Italy - pollen stratigraphy and radiocarbon dating. Boreas 21, 193e208.

Lowe, J.J., Watson, C., 1993. Lateglacial and early Holocene pollen stratigraphy of the northern Apennines, Italy: a contribution to the 'North Atlantic seaboard pro-gramme' of IGCP-253, 'Termination of the Pleistocene'. Quat. Sci. Rev. 12 (8), 727 e738.

Lowe, J.J., Accorsi, C., Bandini Mazzanti, M., Bishop, A., van der Kaars, S., Forlani, L., Mercuri, A.M., Rivalenti, C., Torri, P., Watson, C., 1996. Pollen stratigraphy of sedimen sequences from lakes Albano and Nemi (near Rome) and from the central Adriatic, spanning the interval from oxygen isotope Stage 2 to the present day. In: Oldfield, F., Guilizzoni, P. (Eds.), Palaeoenvironmental Analysis of Italian Crater Lake and Adriatic Sediments, Memorie dell'Istituto Italiano di Idrobiologia. 55, pp. 71e98.

Magny, M., Combourieu-Nebout, N., de Beaulieu, J.-L., Bout-Roumazeilles, V., Colombaroli, D., Desprat, S., Francke, A., Joannin, S., Ortu, E., Peyron, O., Revel, M., Sadori, L., Siani, G., Sicre, M.A., Samartin, S., Simonneau, A., Tinner, W., Vanniere, B., Wagner, B., Zanchetta, G., Anselmetti, F., Brugiapaglia, E., Chapron, E., Debret, M., Desmet, M., Didier, J., Essallami, L., Galop, D., Gilli, A., Haas, J.N., Kallel, N., Millet, L., Stock, A., Turon, J.L., Wirth, S., 2013. Northesouth palaeohydrological contrasts in the central Mediterranean during the Holocene: tentative synthesis and working hypotheses. Clim. Past 9, $2043 e 2071$.

Magny, M., Vanniere, B., Beaulieu, J.-L. de, Begeot, C., Heiri, O., Millet, L., Peyron, O., Walter-Simonnet, A., 2007. Early-Holocene climatic oscillations recorded by lake-level fluctuations in west-central Europe and in central Italy. Quat. Sci. Rev. 26, 1951e1964.

Magri, D., 1999. Late Quaternary vegetation history at Lagaccione near Lago di Bolsena (central Italy). Rev. Palaeobot. Palynol. 106, 171e208.

Magri, D., Parra, I., 2002. Late Quaternary western Mediterranean pollen records and African winds. Earth Planet. Sci. Lett. 200 (3e4), 401e408.

Magri, D., Sadori, L., 1999. Late Pleistocene and Holocene pollen stratigraphy at Lago di Vico (central Italy). Veg. Hist. Archaeobot. 8, 247e260.

Magri, D., Vendramin, G.G., Comps, B., Dupanloup, I., Geburek, T., Gomory, D., Latalowa, M., Litt, T., Paule, L., Roure, J.M., Tantau, I., van der Knaap, W.O., Petit, R.J., Beaulieu, J.-L. de, 2006. A new scenario for the Quaternary history of European beech populations: palaeobotanical evidence and genetic conse-quences. New Phytol. 171, 199e221.

Marchini, G., Zanchetta, G., Santacroce, R., Vigliotti, L., Capotondi, L., Sulpizio, 2014 Tephrostratigraphy of Marine core AD91-17 (Adriatic Sea) revised. Alp. Medi-terr. Quat. 27 (2), $77 \mathrm{e} 84$.

Marianelli, P., Sbrana, A., 1998. Risultati di misure di standard di minerali e di vetri naturali in microanalisi a dispersione di energia. Atti Soc. Toscana Sci. Nat. Mem. Ser. A 105, 57e63.

Mayewski, P.A., Eelco, E.R., Stager, J.C., Karlen, W., Maasch, K.A., Meeker, L.D., Meyerson, E.A., Gasse, F., van Kreveld, S., Holmgren, K., Lee-Thorp, J., Steig, E.J., 2004. Holocene climate variability. Quat. Res. 62, 243e255.

Moore, P.D., Webb, J.A., Collinson, M.E., 1991. Pollen Analysis. Blackwell Scientific Publications, London.

Ogniben, L., 1973. Schema geologico della Calabria in base ai dati odierni. Geol. Romana 12, 243e585.

Paterne, M., Guichard, F., Labeyrie, J., 1988. Explosive activity of the South Italian volcanoes during the past 80,000 years as determined by marine teph-rochronology. J. Volcanol. Geotherm. Res. 34, 153e172.

Peyron, O., Magny, M., Goring, S., Joannin, S., Beaulieu, J.-L. de, Brugiapaglia, E. 
Sadori, L., Garfi, G., Kouli, K., Combourieu-Nebout, N., 2013. Contrasting patterns of climatic changes during the Holocene in central Mediterranean area (Italy) reconstructed from pollen data. Clim. Past 9, 1233e1252.

Ponel, P., Lowe, J.J., 1992. Coleopteran, Pollen and Radiocarbon Evidence from the Prato Spilla 'D' Succession, N. Italy. In: Comptes Rendues de l'Academie des Sciences, Paris, 315, Ser. II, pp. 1425e1431.

Quezel, P., Medail, F., 2003. Ecologie et biogeographie des forets^ du bassin mediterraneen. Elsevier, Collection Environnement, Paris, 573 p.

Rasmussen, S.O., Andersen, K.K., Svensson, A.M., Steffensen, J.P., Vinther, B.M., Clausen, H.B., Siggaard-Andersen, M.-L., Johnsen, S.J., Larsen, L.B., Bigler, M., Rothlisberger,€ R, Fischer, H., Goto-Azuma, K., Hansson, M.E., Ruth, U., 2006.

A new Greenland ice core chronology for the last glacial termination. J. Geophys. Res. 111, $1 \mathrm{e} 16$.

Reille, M., 1992e1998. Pollen et Spores d'Europe et d'Afrique du nord. Laboratoire de Botanique Historique et Palynologie. Universite d'Aix-Marseille.

Reimer, P.J., Bard, E., Bayliss, A., Beck, J.W., Blackwell, P.G., Ramsey, C.B., Buck, C.E., Burr, C.H., Edwards, R.L., Friedrich, M., Grootes, P.M., Guilderson, Haflidason, H., Hajdas, I., Hatte, C., Heaton, T.J., Hoffmann, D.L., Hogg, A.G., Hughen, K.A., Kaiser, K.F., Kromer, B., Manning, S.W., Niu, M., Reimer, R.W., Richards, D.A., Scott, E.M., 2013. INTCAL13 and MARINE13 radiocarbon age calibration curves, 0-50,000 years cal BP. Radiocarbon 55 (4), 1869e1887.

Rivas-Martinez, S., 1993. Bases para una nueva clasificacion bioclimatica de la tierra. Folia Bot. Madritensis 10, 1e23.

Sadori, L., 2013. Southern Europe. In: Elias, S.A. (Ed.), The Encyclopedia of Quater-nary Science, vol. 4. Elsevier, Amsterdam, pp. 179e188.

Sadori, L., Narcisi, B., 2001. The Postglacial record of environmental history from Lago di Pergusa, Sicily. Holocene 11 (6), 655e671.

Sadori, L., Zanchetta, G., Giardini, M., 2008. Last Glacial to Holocene palae-oenvironmental evolution at Lago di Pergusa (Sicily, Southern Italy) as inferred by pollen, microcharcoal, and stable isotopes. Quat. Int. 181, 4e14.

Siani, G., Magny, M., Paterne, M., Debret, M., Fontugne, M., 2013. Paleohydrology reconstruction and Holocene climate variability in the South Adriatic sea. Clim. Past 9, $499 \mathrm{e} 515$.

Siani, G., Paterne, M., Michel, E., Sulpizio, R., Sbrana, A., Arnold, M., Haddad, G., 2001. Mediterranean sea-surface radiocarbon reservoir age changes since the last glacial maximum. Science 294, 1917e1920.

Siani, G., Sulpizio, R., Paterne, M., Sbrana, A., 2004. Tephrostratigraphy study for the last $18,000{ }^{14} \mathrm{C}$ years in a deep-sea sediment sequence for the South Adriatic. Quat. Sci. Rev. 23, 2485e 2500 .

Smith, V.C., Isaia, R., Pearce, N.J.G., 2011. Tephrostratigraphy and glass composition of post15 kyr Campi Flegrei eruptions: implications for eruption history and chronostratigraphic markers. Quat. Sci. Rev. 30, 3638e3660.

Spada, F., Cutini, M., Paura, B., 2010. Floristic changes along the topographical gradient in montane grasslands in Monti Picentini (Campania, SW Italy). Ann. Bot. (Roma) 21, $115 \mathrm{e} 122$

Spampinato, G., Bernardo, L., Passalacqua, N.G., 2010. La serie di vegetazione delle Regione Calabria. In: Blasi (Ed.), La Vegetazione d'Italia con Carta delle Serie di Vegetazione in scala 1: 500 000. Palombi and Partner S.r.L., Roma.

Sperone, E., Bonacci, A., Brunelli, E., Corapi, B., Tripepi, S., 2007. Ecologia e con-servazione dell'erpetofauna della Catena Costiera Calabra. Studi Trent. Sci. Nat. Acta Biol. 83, $99 \mathrm{e} 104$.

Sulpizio, R., van Welden, A., Caron, B., Zanchetta, G., 2010. The Holocene tephros-tratigraphy of Lake Shkodra (Albania and Montenegro). J. Quat. Sci. 25 (5), 633 e650.
Thompson, R., Oldfield, F., 1986. Environmental Magnetism. Allen and Unwin, London.

Tomlinson, E.L., Arienzo, I., Civetta, L., Wulf, S., Smith, V.C., Hardiman, M., Lane, C.S., Carandente, A., Orsi, G., Rosi, M., Muller, W., Menzies, M.A., 2012. Geochemistry of the Phlegraean Fields (Italy) proximal sources for major Mediterranean tephras: implications for the dispersal of Plinian and co-ignimbritic compo-nents of explosive eruptions. Geochim. Cosmochim. Acta 93, 102e128.

Tinner, W., Colombaroli, D., Heiri, O., Henne, P.D., Steinacher, M., Untenecker, J., Vescovi, E., Allen, J.R.M., Carraro, G., Conedera, M., Joos, F., Lotter, A.F., Luterbacher, J., Sanmartin, S., Valsecchi, V., 2013. The past ecology of Abies alba provides new perspectives on future responses of silver fir forests to global warming. Ecol. Monogr. 84 (4), $419 \mathrm{e} 439$.

Van der Plicht, J., van Geel, B., Bohncke, S.J.P., Bos, J.A.A., Blaauw, M., Speranza, A.O.M., Muscheler, R., Bjorck,€ S., 2004. The Preboreal climate reversal and a subsequent solar-forced climate shift. J. Quat. Sci. 19 (3), 263e269.

Van Raden, U.J., Colombaroli, D., Gilli, A., Schwander, J., Bernasconi, S.M., van Leeuwen, J., Leuenberger, M., Eicher, U., 2013. High-resolution late-glacial chronology for the Gerzensee lake record (Switzerland): $\mathrm{d}^{18} \mathrm{O}$ correlation be-tween a Gerzensee-stack and NGRIP. Palaeogeogr. Palaeoclimatol. Palaeoecol. 391 (B), $13 e 24$.

Vanniere, B., Magny, M., Joannin, S., Simonneau, A., Wirth, S.B., Hamann, Y., Chapron, E., Gilli, A., Desmet, M., Anselmetti, F.S., 2013. Orbital changes, varia-tion in solar activity and increased anthropogenic activities: controls on the Holocene flood frequency in the Lake Ledro area, Northern Italy. Clim. Past 8, 4701e4744.

Van Dijk, J.P., Bello, M., Brancaleoni, G.P., Cantarella, G., Costa, V., Frixa, A., Golfetto, F., Merlini, S., Riva, M., Torricelli, S., Toscano, C., Zerilli, A., 2000. A regional structural model for the northern sector of the Calabrian Arc (southern Italy). Tectonophysics 324, 267 e320.

Vettori, C., Vendramin, G.G., Anzidei, M., Pastorelli, R., Paffetti, D., Giannini, R., 2004. Geographic distribution of chloroplast variation in Italian populations of beech (Fagus sylvatica L.). Theor. Appl. Genet. 109, 1 e9.

Vogel, H., Zanchetta, G., Sulpizio, R., Wagner, B., Nowaczyk, N., 2010. A tephrostratigraphic record for the last glacial-interglacial cycle from Lake Ohrid, Albania and Macedonia. J. Quat. Sci. 25 (3), 320e338.

Watson, C.S., 1996. The Vegetational History of the Northern Apennines, Italy: in-formation from three new sequences and a review of regional vegetational change. J. Biogeogr. 23 (6), 805e841.

Watts, W.A., Allen, J.R.M., Huntley, B., Fritz, S.C., 1996. Vegetation history and climate of the last 15,000 years at Laghi di Monticchio, southern Italy. Quat. Sci. Rev. 15, $113 \mathrm{e} 132$.

Whitlock, C., Briles, C.E., Fernandez, M.C., Gage, J., 2011. Holocene vegetation, fire and climate history of the Sawtooth Range, central Idaho, USA. Quat. Res. 75, 114e124.

Wulf, S., Kraml, M., Brauer, A., Keller, J., Negendank, J.F.W., 2004. Tephrochronology of the 100 ka lacustrine sediment record of Lago Grande di Monticchio (southern Italy). Quat. Int. 122, 7 e30.

Wulf, S., Kraml, M., Keller, J., 2008. Towards a detailed distal tephrostratigraphy in the Central Mediterranean: the last 20,000 yrs record of Lago Grande di Monticchio. J. Volcanol. Geotherm. Res. 177, 118e132.

Zanchetta, G., Sulpizio, R., Roberts, N., Cioni, R., Eastwood, W.J., Siani, G., Caron, B., Paterne, M., Santacroce, R., 2011. Tephrostratigraphy, chronology and climatic events of the Mediterranean basin during the Holocene: an overview. Holocene 21, $33 e 52$. 